\title{
Bölgesel Krizlerde Birleşmiş Milletler ve Ukrayna Krizi
}

\author{
United Nations in Regional Crises and Crisis in Ukraine
}

Aslihan ANLAR ${ }^{1}$

Geliş tarihi: 06.06.2018, Kabul tarihi: 16.12.2018, Basım tarihi: 01.05.2019

\section{Öz}

Birleşmiş Milletler (BM), uluslararası barış ve güvenliğin korunması için kurulmuş en kapsamlı uluslararası örgüttür. Bölgesel krizlerin tırmandırılmadan çözülmesinde etkin rol oynayabilecekken, BM Güvenlik Konseyi daimi üyelerinden birinin taraf olduğu krizlerde bu durum Konseyin önünü kesmektedir. Bu çalışma temel olarak BM'in Ukrayna krizi esnasında gösterdiği faaliyetlere odaklanmaktadır. Ukrayna temsilcisinin BM'e mektup gönderdiği tarih olan 28 Şubat 2014- Şubat 2017 arasındaki zaman dilimine bakılacaktır. Çalışmada tamamen birincil kaynaklar olan BM organlarının yayınladığı kararlar, karar tasarıları, bilgilendirme metinleri, proje raporları, plan değerlendirme metinleri taranmıştır. Ukrayna'da yaşanan gerilim BM Güvenlik Konseyi'nin yetersizliğini gözler önüne seren diğer bir örneği teşkil etmiştir. Güvenlik Konseyi ve Genel Kurul dışındaki BM program ve fonları ise çatışmalar önlenemeyince devreye girmişlerdir. Çatışmalar tırmanmadan önce bu sorun gündemine gelmesine rağmen bu sorunun çözümünde başarılı olamamışır.

Anahtar Kelimeler: Birlesmiş Milletler, Ukrayna, bölgesel krizler, Güvenlik Konseyi, BM Insani Işler Koordinasyon Ofisi, Birlesmis Milletler Mülteciler Yüksek. Komiserliği

Jel Kodlar1: F50, F51, F53

\begin{abstract}
The United Nations is one of the most important international organizations, have being established for peace and security. Besides the Security Council, there are lots of organizations under the UN umbrella. This study focuses on activities and performance of the UN during the period from 28 February 2014 (date of submission of Ukraine UN representative's letter to the UN Security Council) to February 2017. While preparing this study, only primary resources, especially UN Security Council resolutions, resolution drafts, meeting records, press statements, assessment reports are reviewed. This tension generates an additional example which clearly displays inefficiency of the UN Security Council mechanism. Other councils began their activities after failures of the UN Security Council and General Assembly. Despite the fact that this issue was put on its agenda before escalation of the conflict, it cannot be successful at keeping peace in Ukraine.
\end{abstract}

Keywords: United Nations, Ukraine, regional crises, Security Council, UN Office for the Coordination and Humanitarian Affairs, UN Refugee Agency

Jel Codes: F50, F51, F53

\footnotetext{
${ }^{1}$ Kocaeli Üniversitesi, İktisadi İdari Bilimler Fakültesi, Uluslararası İlişkiler Bölümü, Dr. aslihan.anlar@gmail.com / aslihan.anlar@kocaeli.edu.tr

http://orcid.org/0000-0002-0591-8764
} 


\section{Giriş}

Birleşmiş Milletler (BM), uluslararası barış ve güvenliğin korunması için kurulmuş en kapsamlı uluslararası örgüttür. BM Şartı'nın ilk maddesinde ilk fikrasında amaçları şu şekilde sıralanmıştır:

"Uluslararası barış ve güvenliği korumak ve bu amaçla:

$\checkmark$ Barışın uğrayacağı tehditleri önlemek ve bunları boşa çıkarmak,

$\checkmark$ Saldırı ya da barışın başka yollarla bozulması eylemlerini bastırmak üzere etkin ortak önlemler almak ve

$\checkmark$ Barısıı bozulmasına yol açabilecek nitelikteki uluslararası uyuşmazlık veya durumların düzeltilmesini ya da çözümlenmesini barışçı yollarla, adalet ve uluslararası hukuk ilkelerine uygun olarak gerçekleştirmek"tir. (UHDİGM, 1945: 4)

BM Şartının ilk maddesinin ikinci fikrası ise dostça ilişkilerin geliştirilmesi ve dünya barışını güçlendirmek için diğer uygun önlemlerin alınmasına değinmekteyken; üçüncü fikra "ekonomik, sosyal, kültürel ve insancil nitelikteki uluslararası sorunları çözmede ve ırk, cinsiyet, dil ya da din ayrımı gözetmeksizin herkesin insan haklarına ve temel özgürlüklerine saygının geliştirilip güçlendirilmesinde uluslararası işbirliğini sağlamak" olarak belirtilmiştir (UHDİGM, 1945: 5). Uluslararası barışın ve güvenliğin korunmasında başlıca sorumluluk Güvenlik Konseyi'ndedir. (Madde 24) (UHDİGM, 1945: 11)

Ancak BM birinci fikradaki amaçları gerçekleştirmekte pek çok nedenlerle başarısız olmakla, yeterince etkin olmamakla eleştirilmiştir. Ne yazık ki Ukrayna'daki kriz esnasında gösterilen zayıf performans bunun örneklerinden biri olmuştur. Ukrayna temsilcisinin konuyu BM gündemine taşımasına rağmen BM Güvenlik Konseyi ne 6. Bölüm'de ne de 7 . Bölüm'deki belirlenen yöntemleri hayata geçirememiş ve çatışmalar daha da kızışarak devam etmiş̧ir. BM en başta engelleyemediği yıkımı daha sonra tamir yoluna gitmiş ve BM çatısı altında pek çok yardım kuruluşu Güvenlik Konseyi'nin taraflar arası uzlaşma sağlayamadığı çatışmanın hayatlarını mahvettiği insanlara yardım kampanyaları düzenlemiş ve program, proje ve planları geliştirmiştir. Bölgedeki insanların durumlarını bir parça düzeltmesi için milyonlarca dolar harcanmıştır.

Bu çalış̧ma da temel olarak BM'in Ukrayna krizi esnasında gösterdiği performans değerlendirilecektir. Zamanlama olarak Ukrayna temsilcisinin BM'e mektup gönderdiği tarih olan 28 Şubat 2014- Şubat 2017 arasındaki zaman dilimine bakılacaktır. Çalışmada tamamen birincil kaynaklar olan BM organlarının yayınladığı kararlar, karar tasarıları, bilgilendirme metinleri, proje raporları, plan değerlendirme metinlerinden yararlanılarak yapmış olduğu faaliyetler ortaya konulacaktır. İlk olarak Güvenlik Konseyi, sonraki bölümlerde kriz esnasında faaliyet gösteren diğer BM organlarına 
bakılacaktır. Ancak organların faaliyetleri incelemeye geçilmeden önce çok kısa da olsa literatür taramasına yer verilecektir. Son bölümde faaliyetleri ortaya konan organların performansları değerlendirilecektir.

\section{Literatür Taraması}

Kaynak taraması yapıldığında literatürde çok sınırlı sayıda yayının bu konuya değindiği görülmektedir. BM ve Ukrayna hakkında sayısız eser olmakla beraber BM'in Şubat 2014'de başlayan krizle ilgili olarak Ukrayna'daki varllğı az sayıda eserde görülmekte ya da geçmektedir.

İlk olarak Roy Allison'in International Affairs'de Kasım 2014'de yayınlanan makalesinde Rusya'nın Kırım ve Ukrayna'daki politikası ile Soğuk Savaş sonrası Avrupa'daki sisteme tamamen meydan okumasına rağmen Rusya'nın uluslararası ortamda istikrarlı bir şekilde herhangi bir yanlış yaptığını ya da yasalara aykırı olarak askeri müdahalede bulunduğu iddialarını reddettiğini ifade etmiştir. Bu çerçevede Rusya'nın 1 ve 3 Mart 2014 tarihlerindeki Güvenlik Konseyi toplantılarında Ukrayna meselesi ile ilgili söylemlerini sıralamış ve bunların geçersizliğini ortaya koymuştur. (Allison, 2014: 1261-1268) Allison'un bu makalesindeki amacı Rusya'nın politikasını açıklamak olup, BM ile ilgili bir değerlendirme yapmamıştır.

Bilal Karabulut BM'in barış ve güvenliği korumadaki rolünü tartıştı̆̆ makalesinin ikinci kısmında BM'in yeni güvenlik alanlarının hepsinde faaliyetler yürütmekte olduğunu belirtip, Karadeniz Havzası'nda çevre güvenliği ile ilgili girişimlerini tanımlayıp değerlendirmiştir. Karabulut'a göre BM Karadeniz'in çevresel güvenliği konusunda en aktif rol oynayan uluslararası aktör olmasına rağmen sonuç alıcı strateji ve planlar ortaya koyamamıştır. (Karabulut, 2015: 54-55)

Mehmet Sait Dilek "Rusya Federasyonu'nun Kurım Hamlesine Analitik Bakış" isimli makalesinde çok kısa olarak Rusya'nın Kırım'a ilişkin karar tasarısını veto ettiğini belirterek bu durumun Güvenlik Konseyi’nin antidemokratik yapısına işaret ettiğini ifade etmiştir. (Dilek, 2015: 257)

Richard Gowan BM Güvenlik Konseyi'ndeki Rusya ve Çin'in veto hakkında doğan sorunları incelediği makalesinde BM'nin Ukrayna meselesinde, Güvenlik Konseyi'nin Rusya ve Batılı devletlere, verimli bir diplomatik görüşme yerine birbirlerine suçlamalarını yönetebilecekleri bir platform sunmaktan başka bir rol oynayamadığını belirtmiştir. Aşağı da ele alınacak olan BM GK 2202 no'lu kararının Rusya'nın koşullarını ortak bir kararmış gibi sunulmasına sebep olduğunu ifade etmiştir. (Gowan, 2015: 5)

Jean- Dominique Guiliani de Rusya'nın Ukrayna'ya müdahalesinin uluslararası hukuka etkisini tartışı̆ğı çalışmasında Rusya'nın Kırım ilhakıyla BM Şartı'nın, Avrupa Konseyi Tüzügü'nün, Helsinki Konferansı Nihai Senedi’nin, BDT’YI kuran Anlaşma'nın, Ukrayna ve Rusya arasındaki iki 
anlaşmanın ve Ukrayna ve Kırım'ın anayasalarının ihlali olduğunu ifade etmiştir. Bu ihlalin sadece Kırım ve Ukrayna'yı ilgilendirmediğini, nükleer silahların yayılmasının önlenmesini zorlaştıracağı, azınlık ve kimlik sorunlarını kızıştırabileceği, savaşlarla ilgili düzenlemelerin zayıflatıldığını iddia etmiş ve bu sürecin "hukuk devletler ve bireyler arası ilişkilerin yürütülmesinde en iyi yöntemdir" inancını değiş̧irmemesi gerektiğini vurgulamıştır. (Guiliani, 2015: 6)

Görüldüğ̈̈ üzere BM ve Ukrayna üzerindeki yazın daha çok Şubat ve Mart 2015 tarihinden sonra, özellikle Kırım'ın ilhakı üzerine ve Güvenlik Konseyi'nin Rusya'dan kaynaklanan etkin faaliyet gösterememe durumu üzerinde durulmuştur. Bu çalışmada Güvenlik Konseyi'ndeki gelişmeler Ağustos 2016'ya kadar ele alınacak, ayrıca diğer devletlerin tutumunun yanı sıra BM İnsan Hakları Yüksek Komiserliği, AGITT Gözlem Misyonu ve BM İnsani İşler Koordinasyon Ofisi'nin bilgilendirme konuşmalarına da değinilecek ve ikinci kısımda BM'nin diğer organ ve programlarının faaliyetleri de ele alınacaktır.

\section{Güvenlik Konseyi}

Birleşmiş Milletler Güvenlik Konseyi 28 Şubat 2014'de Ukrayna'nın daimi temsilci Yuriy Sergeyev'in Ukrayna'nın toprak bütünlügünün tehlikede olduğunu ifade eden mektubu üzerine ilk toplantısını yapmıştır. BM Güvenlik Konseyi 28 Şubat ile Ağustos 2016 tarihleri arasında kırk toplantı gerçekleştirmiş̧tir. Bu toplantıların dört tanesi 2014 Martında Kırım'ın Rusya Federasyonu'na bağlandığı tarihten önce yapılmıştır. Bu toplantılara Ukrayna daimi temsilcisi de katılmış, zaman zaman AGíT'ten ya da BM İnsan Hakları Yüksek Komiserliği ve BM İnsani İlişkiler Koordinasyon Ofis'inden konuyla ilgili yetkililer de davet edilmiştir.

BM konuyla ilgili olarak Ukrayna'daki durumu yerinde incelemek üzere BM Genel sekreter yardımcısı Jan Eliasson'u görevlendirmiştir. Daha sonra BM Genel Sekreteri Siyasi İşlerden Sorumlu Yardımcısı Oscar Fernandez Taranco, Jeffrey Feltman ve Taye- Brook Zerihoun, Jens Anders ToybergFrandzen; BM Genel Sekreteri İnsan Haklarından Sorumlu Yardımcısı İvan Simonoviç, BM İnsani İşler Koordinasyon Ofisi (OCHA) Direktörü John Ging görevlendirilmiştir. Bu üst düzey yetkililer Ukrayna'daki gelişmeleri takip etmiş ve güvenlik konseyini bilgilendirmişlerdir. Görüşmelere aynı zamanda AGİT’ten Büyükelçi Ertuğrul Apakan, AGİT Ukrayna Özel Gözlem Misyonu Başkanı ve Büyükelçi Heidi Tagliavini, AGíT Kiev temsilcisi davet edilmiş ve bilgi verilmesi istenmiştir.

Bu toplantilarda Rusya Federasyonu'nun ve Ukrayna ve onu destekleyen devletlerin konu ile ilgili sundukları tezlerden bahsetmek gerekirse, 6 temel başlıkta tartışmalar süregitmiştir. (UN Security Council, 2014a, 2014b, 2014c, 2014ç) 
1. Rusya Federasyonu Ukrayna'da olayların tırmandırilmasindan Ukrayna'daki muhalefeti ve muhalefet içinde radikal aşırı grupların olduğu iddiasıyla onları sorumlu tutmuştur.

2. Ulusal birlik hükümetinin oluşturulması, anayasal reformlar ve yeni anayasa, Aralık 2014'de başkanlık seçimleri ve silahlı güçlerin kullanılmamasını öngören 21 Şubat Anlaşmasının uygulanmadığını Rusya ileri sürmüştür.

3. Ukrayna Parlamentosu'nun Ukrayna'daki azınlıkların kendi dillerini kullanmalarını düzenleyen kanunu değiştirmiş olmaları da Rusya tarafindan eleştirilmiş ve durumun Ukrayna tarafindan tırmandırılmasına kanıt olarak gösterilmiştir.

4. Rusya'dan hem Yanikoviç hem de Kırım özerk Bölgesi Başbakanı Aksyonov tarafindan yardım talebinde bulunduklarını Rusya temsilcisi ileri sürmüştür.

5. Ukrayna'daki gelişmelerin hem Ukrayna'daki Rusya vatandaşlarını, Rusça konuşanları ve Rusya Federasyonu Karadeniz Filosu 'nu ve görevlilerini tehdit ettiğini, Rusya'nın onları korumayı amaçladıkları ve Kırım'da düzenin tekrar tesis edilmesini amaçladıklarını ileri sürmüşlerdir.

6. Ukrayna'da yaşananların demokrasi olmadığı, aksine güç kullanan bir ele geçirme süreci olduğunu söylemiştir. Buna karşın Ukrayna temsilcisi de Yanikoviç hakkındaki kararın Ukrayna Parlamentosu tarafından alındığını ve Parlamentonun devrimle değil normal bir seçim süreci sonunda iş başına geldiğini dile getirmiştir.

7. Kırım'da düzenlenen referanduma yönelen eleştirilere Rusya Kosova örneğini öne sürmüş, ABD'nin bağımsızlık kazanma sürecinden bahsetmiştir.

Karşı taraf ise

1. Rusya'yı, tüm uluslararası hukuku, imzacısı olduğu Budapeşte Memorandumu 'nu, 1997 tarihli Rusya Federasyonu ve Ukrayna Dostluk, İşbirliği ve Ortaklık Antlaşması'nın hükümlerini çiğneyerek Kırım'ı işgal etmekle suçlamış ve işgale son verme ve askeri birliklerini çekme çağrısında bulunmuşlardır.

2. Rusya'nın beşinci argümanına karşı Rusya'nın askeri operasyonunun kesinlikle insan hakları koruma misyonu olmadığı ve aksine Rus ya da Rusya yanlısı kesimlere karşı şiddet uygulandığına ya da uygulanacağına dair bir göstergenin bulunmadığına işaret edilmiştir. 
3. Rusya'nın dördüncü argümanına karşı olarak da Kırım Parlamentosu'nun ya da yönetiminin böyle bir hakkı olamadığı, bu hakkın ancak Ukrayna ulusal Meclisi’nde olduğu ileri sürülmüştür. Ayrıca Yanukoviç'in eski Başkan olduğu ve kendi ülkesini terk ederek kaçtığını, bu sebeple O'nun davetinin geçerli bir sebep olamadığ da söylenmiştir.

4. Rusya'nın askeri hareketinin kesinlikle barışı koruma misyonu olarak kabul edilemeyeceğini, açıkça bir saldırı olduğu söylenmiş ve kınanmiştır.

5. Rusya'nın 21 Şubat anlaşmasını öne sürmesine karşı da taraflardan biri olan Ukrayna eski devlet başkanının kaçtığ1 için anlaşmanın uygulanmasına imkân kalmadığı da dile getirilmiş̧tir. Rusya da buna karşın yine de anlaşmaya uyulabileceğini böylece olaylar tırmanmadan çözülebileceğini ifade etmiştir.

6. Ukrayna temsilcisi ayrıca Rusya'nın üçüncü argümanına karşı Ukrayna'nın Avrupa Bölgesel Azınlık Dilleri Şartı'nı imzaladıklarını ve 1992 tarihinde bağımsızlkklarında hemen sonra etnik azınlıkların haklarının korunmasını düzenleyen kanun çıkardıklarını da dile getirmiştir.

Mart 2014 sonras1 ise Nisan'da Donetsk ve Luhansk'ta gösteri ve ayaklanmaların artması ve 13 Nisan'da Ukrayna'nın askeri operasyona başlamasıyla BM GK'ndeki tartışmalar da başka mecraya taşınmıştır. Rusya Federasyonu temsilcisi kendini yetkili gören Kiev'deki otoritelerin darbeye varan dikkatsiz hareketlerinin Ukrayna'nın kırilgan toplumsal yapisina tamamen zarar vereceğini ifade etmiş ve yönetimin radikal milliyetçiler, şovenişt, anti-Semitist ve Rus düşmanı kişilerden olduğu iddiası Ukrayna yönetimini suçlamışır. (UN Security Council, 2014d: 2) 13 Nisan görüşmeleri boyunca tüm Konsey üyelerine ve Ukrayna temsilcisine 14 Nisan'da başlayacak olan terörizm karşı1tı askeri operasyonun yapılmaması yönünde uyarılarda bulunmuştur. (UN Security Council, 2014d: 17)

Ancak Konsey'in diğer üyeleri asker üniformalı grupların hükümet binalarını işgal ettiğini, yollara barikatlar kurulduğunu, bu eylemlerin nizamsız bir güruh tarafindan değil, profesyonel askerler tarafindan yapıldığını, Rusya'nın sınıra askeri yığınak yaptığını ve buna benzer bir sürecin Kırım'da da yaşandığını iddia ederek Rusya'yı suçlamışlar ve Ukrayna'ya destek çıkmışlardır. (UN Security Council, 2014d: 5) Ukrayna temsilcisi ayrıca Rusya'ya Ukrayna topraklarında karışıklık çıkarmak üzere özel görevli gruplar oluşturup göndermekle itham etmiştir. (UN Security Council, 2014d: 13) BM İnsan Hakları Yüksek Komiserliği tarafından yayınlanan raporlara dayanarak Ukrayna'da azınlık ya da insan haklar1 konusunda sistematik ihlaller yapılmadığı, dolayısıyla Rusya'nın bu hususları 
gerekçe göstererek Kırım'a müdahil olmasının dayanaksız olduğu ve bu sorunlara barışçıl yollarla uğraşılabilecek boyutta olduğu da defaten dile getirilmiştir. (UN Security Council, 2014e: 4)

Ancak Rusya bu raporun objektif bir şekilde hazırlanmadığını, aksine Ukrayna'daki Rusça konuşan halkın durumunun kötüleştiğini iddia etmiş, Kiev liderlerini Donbas ziyaretinde protestocularla görüssmemekle suçlamıştır. (UN Security Council, 2014e: 7 ve 23) Ukrayna temsilcisinin de davet edildiğinde bu toplantılarda sürekli Ukrayna'da azınlıkların, özellikle Rusça konuşan topluluğun sıkıntı yaşamadığı, anti-Semitizm'in yaygınlaştığına ilişkin bir durumun olmadığını ve Kırım'da asıl insan hakları ihlallerinin Rus işgalinden sonra başladığı, özellikle Kırım Tatarlarına ve Ukrain kökenlilerin sıkıntı çektiği belirtilmiştir. (UN Security Council, 2014e: 19) Buna karşılık, Rus temsilcisi de Kırım'da Tatar dilinin üçüncü resmi dil olarak kabul edildiğini, kabinede bazı bakanlıkların sadece Tatarlara verilmek üzere ayrıldığını ve Kırım Tatarlarının durumunu daha da iyileştirmek üzere Tataristan Cumhuriyeti ile anlaştıklarını ifade etmiştir. (UN Security Council, 2014e: 21)

29 Nisan görüşmelerinde ise 17 Nisan Cenevre'de gerginliğin düşürülmesi ve şiddetin sonlandırılması üzerine anlaşıldığı halde Ukrayna'nın kendi üzerine düşeni yerine getirdiği ancak Rusya'nın siyasetinde herhangi bir değişiklik olmadığı Birleşik Krallık, Fransa, Avusturalya ve ABD temsilcileri tarafindan dile getirilmiş; (UN Security Council, 2014f: 4-7) Rus temsilcisi de bu iddiaları reddederek asıl anlaşmayı uygulamak için somut adımlar atmayan tarafin Ukrayna olduğunu örnekleriyle anlatmıstır (UN Security Council, 2014f: 13).

Ukrayna yönetiminin, ülkenin doğu ve güney bölgelerine yürüttüğü askeri operasyon Rusya tarafindan sürekli eleştirilmiştir. Rusya, Avrupa Birliği ve ABD'yi Ukrayna'ya destek olmakla suçlamış ve olayların tırmandırılmasından bu ülkeleri sorumlu tutmuştur. Rusya 25 Mayıs seçimlerini de desteklemediğini açıklamıştır (UN Security Council, 2014g: 3, 18). Birleşik Krallık ve Fransa temsilcileri Rusya'nın Ukrayna'nın yaptığı operasyonları barışçl göstericilere karş1 yürütülen askeri bir operasyon gibi gördügünü, aksine Ukrayna'nın kendi egemenliğini tesis etmek ve vatandaşlarını korumak üzere Rusya'nın desteklediği silahlı gruplara karşı yürüttüğü bir operasyon olduğunu dile getirmişlerdir. (UN Security Council, 2014g: 4-5)

25 Mayıs seçimleri ve Rusya'nın da bu seçimleri tanıdığını açılaması üzerine Ukrayna üzerine BM Güvenlik Konseyi (BMGK) görüşmeleri barış girişimleri üzerine yoğunlaşmıştır. 24 Haziran BMGK 7205 sayılı toplantısı, Ukrayna yeni devlet başkanı Petro Proşenko'nun 20 Haziran'da ilan ettiği bir haftalık ateşkes ve barış planı; (UN Security Council, 2014̆ğ: 2) Ekim toplantiları da 19 Eylül'de imzalanan Minsk Protokolünün uygulanması üzerine geçmiştir. (UN Security Council, 2014h: 2-3) 
Kötüleşen insani durum da BM Güvenlik Konseyi toplantılarında da ele alınan gündemlerden biri olmuştur. $\mathrm{Bu}$ toplantılar esnasında Rusya Federasyonu Ukrayna'ya insani yardım kafilesi gönderme gerekliliği üzerinden durmuşken, ABD bunun uluslararası Kızıl Haç gibi kuruluşlarca yapılması gerekliliğini, Rusya'nın da bireysel olarak değil bu kuruluşlar üzerinden yardım yapması gerektiğini, aksi halde bunun insani yardım kisvesi altında Ukrayna'ya ekstra müdahale anlamına geleceğini ifade etmişlerdir. (UN Security Council, 20141: 14) Ancak bunlara rağmen Rusya Ağustos (2014) sonlarında Rus insani yardım kafilesi Ukrayna'ya ulaşmışır.(UN Security Council Report, 2016)

5 Eylül Minsk Protokolü'nden sonra BM Güvenlik Konseyi görüşmelerinin ana konusu anlaşmanın uygulanması, yaşanan ihlaller oluşturmuştur. 12 Kasım görüşmelerinde söz alan BM Siyasi İşlerden Sorumlu Genel Sekreter Yardımcısı Toyberg Frandzen yaptığı bilgilendirme konuşmasında Ukrayna için çatışmalara son vermekten başka; çatışmaların yeniden alevlenmesi, zaman zaman artan düşük seviyede devam etmesi ya da yllarca hatta on yıllarca süren donmuş bir ihtilafa çevrilmesi gibi üç seçenek daha bulunduğunu ve bu üç alternatifin önlenmesi gerektiğini belirtmiştir. (UN Security Council, 2014i: 3) ABD temsilcisi ise asıl meselenin uluslararası komitenin Ukrayna'daki olayların bir donmuş ihtilafa dönüşmemesi için ne yapacağ1 olduğunu ifade etmiştir. AGİT’ten temsilcilerinden konuşma yaptığ1 toplantılarda da Ukrayna ve Rusya temsilcileri karşılıklı olarak birbirlerini ateşkesi ihlal etmekle suçlamışlardır. (UN Security Council, 2014i: 17-19 ve 20-23) 23 Ocak 2015'de sözde Donetsk Halk Cumhuriyeti ateşkesten tek taraflı olarak çekildiğini ilan ettiği için bu konu Konsey'in gündeminden çıkmışır.

12 Şubat'taki (2015) yenilenen ateşkes ile BM Güvenlik Konseyi'nin gündemi anlaşmaların uygulanmasına odaklanmıştır. ${ }^{2}$ Silahların geri çekilmesi, ateşkesin uygulanması esnasında özellikle Donetsk'te Horlivka ve Hranite, Mariupol, Marinka ve Debaltseve'deki çatışmalar, AGİT Misyonunun ya da diğer insani yardım amaçlı gelenlerin girişine konulan yasaklar, Kırım Tatarlarının maruz kaldığı insan hakları ihlalleri ele alınmıştır.

Bu görüşmeler esnasında Rusya açıça AGíT Gözlem Misyonu'nun girişini engellemek, yasadışı silahlı grupları desteklemek ve askerini geri çekmemekle suçlanmış ve sonra da ateşkese tam olarak riayet edilmesi için etkisini kullanması istenmiştir. Rusya suçlamaları reddederek, aksine Ukrayna'nın gittikçe silahlandığını (Ukrayna ise bu konuda savunma amaçlı silahlanmanın ya da başka ülkelerden yardım almanın kendisinin hakkı

212 Şubat 2015 tarihli II. Minsk Anlaşması temel olarak ateşkes ve ağır silahların geri çekilmesi, yerel seçimlerin yapılması, Donetsk ve Luhansk önderliğindeki bölgelere daha geniş yetki alanlı özerklik sağlanması ve Ukrayna'nın Rusya'ya sınırında kontrolünün tekrar sağlanması gibi hükümler yer almaktadır. (UN What's in Blue, 2016) 
olduğunu, aksine Rusya'nın silah göndermesinin hangi yasal düzenlemeye dayandığını sormuştur); kendilerinin ağır silahların çekilme işleminin kısmen tamamlandığını ifade etmiştir.

Ayrıca Donbas'taki insani durumun çok kötü olduğunu, Kiev yönetiminin ambargo uyguladığını, maaşların ödenmediğini ve gazın kesildiğini söylemiştir. Rusya'nın oradaki halkın acil ihtiyaçlarını karşılamak için gayret gösterdiğini, 17 insani ihtiyaç maddesi taşıyan konvoy gönderdiklerini, bunlarında Ukrayna sınırdaki gümrük görevlileri tarafından kontrol edildiğini, su, yiyecek ve ilaç temin ettiklerini ifade etmiştir. (UN Security Council, 2015a: 11) 1 milyon yer değiştiren insanların çoğunun (950.000 kişi) Rusya'ya geldiğini, bu insanlara siyasi görüşlerine bakılmaksızın iş ve ev imkânı sağlandığını da sözlerine eklemiştir.

Haziran'daki toplantıda ise Ukrayna'nın Donetsk ve Luhansk'n özerk konumuna ilişkin düzenlemelerin, Misnk'te anlaşıldığı halde yapmadığı, af yasasını halen çıkarmadığı, aksine silahlandığı; Kiev'in bu şekilde devam etmesi halinde Ukrayna'daki durumun tekrar kontrolden çıacağı konularında uyarmıştır. (UN Security Council, 2015b: 9)

Aralık 2015 tarihli BMGK görüşmelerinde Ertuğrul Apakan da bir bilgilendirme konuşması yapmış ve ateşkesin büyük ölçüde uygulandığını ancak halen ihlallerin yaşandığını, bunun da normalleşme ve krizin siyasi çözüme ulaştırılması önünde engel olduğu ifade edilmiştir. Daha sonra ağır silahların geri çekilmesi, mayınlardan temizlenmesi, acilen ihtiyaç duyulan altyapının tamiri ve siyasi anlaşmanın sağlanması konularına değinmiştir. (UN Security Council, 2015c, 9)

Litvanya temsilcisi bu sorunun da donmuş ihtilaflar listesine gireceği uyarısında bulunmuş, Fransız temsilcisi de çözüm sürecine olan destekleri ve bunun sonucu olarak Ukrayna ile Rusya arasında imzalanan yeni doğal gaz anlaşmasına değinmiştir. (UN Security Council, 2015c, 9 ve 11) Nisan ayındaki toplantıda ise Donbas'taki yerel seçimler için yasal düzenlemenin gerekliliğine dikkat çekmiştir. (UN Security Council, 2016, 10) İngiliz temsilcisi ise Rusya'nın hem siyasi çözüme ulaşılması hem de insani durumun düzeltilmesi konusunda en etkili aktör olarak çözüm için gerekli çabayı göstermeye davet etmiştir. (UN Security Council, 2015c, 12) Amerikan temsilcisi de Ukrayna'nın içinde bulunduğu durum ve çözüme ulaşılamamasının sorumlusunun Rusya olduğunu açıkça ifade etmiştir. (UN Security Council, 2015c, 25) Rusya temsilcisi ise yine Ukrayna'daki olayların sorumlusunun dış destekli aşırı grupların yaptığı darbe olduğunu tekrar vurgulamış ve Minsk ateşkesiyle getirilen fakat Ukrayna hükümeti tarafından uygulanmayan yükümlülüklerinden bahsetmiş̧ir. Toplantıya davet edilen Ukrayna Dışişleri Bakanı ise Ukrayna hükümetinin yükümlülüklerini yerine getirdiğini, merkezi yapıyı güçsüzleştiren, yerine Donetsk ve Luhansk yerel yönetime özel düzenleme getiren anayasal değişikliğini kabul ettiklerini, yerel 
seçimlere düzenleme getiren yasa üzerinde çalıştıklarını ancak Rusya'nın üzerine düşeni yapmadı̆̆ını, aksine ateşin kesilmesini beklerken ateşkes tarihinden bu yana $13.500 \mathrm{kez}$ saldırıya uğradıklarını ifade etmiştir. (UN Security Council, 2015c, 26)

Güvenlik Konseyi'nin Ağustos 2016 tarihinde yaptığ1 toplantıda ise Rusya'nın Kırım'daki sabotaj ve terör olaylarının sorumlusunun Ukraynalı güçler olduğu iddiaları yüzünden Rusya ile Ukrayna arasında artan gerilim konu edinmiştir. Ukrayna temsilcisi bu iddiaları tamamen reddederek, Rusya'y1 Doğu Ukrayna'da gerginliği arttıracak eylemlerde bulunmakla suçlamıştır. Rusya iddialarında 1srar etmiş, Ukrayna’yı kınamış ve Minsk Anlaşması'nı uygulanmasını engellemekle suçlamıştır. (UN Security Council Report, 2016)

2 Şubat 2017 tarihli son toplantıda Ukrayna'daki ateşkes ihlalleri, Avdiivka, Yasnuvata, Donestsk havalalanı, Mariupol, Popasna ve Debeltseve bölgelerinde yer alan çatışmalar, ateşkesçe yasaklanan ağır silah kullanımı, sivil ölümleri, bu çatışmaların sebep olabileceği çevresel felaketler ve altyapının zedelenmesiyle mağdur olan sivillerin sorunları, insani yardım kuruluşlarına ve AGİT misyonun geçişlerine bazı bölgelerde izin verilmemesi sorunu ele alınmış ve Ukrayna sorununun dördüncü yılının tamamlandığı, Minsk Ateşkesi ve buna ilişkin GK kararının üzerinden iki y1l geçtiği ifade edilmiştir. (UN Security Council, 2017a, 2-3)

\section{Şekil -1: BM Güvenlik Konseyi'nde Bahsi Geçen Çatışma Bölgeleri}

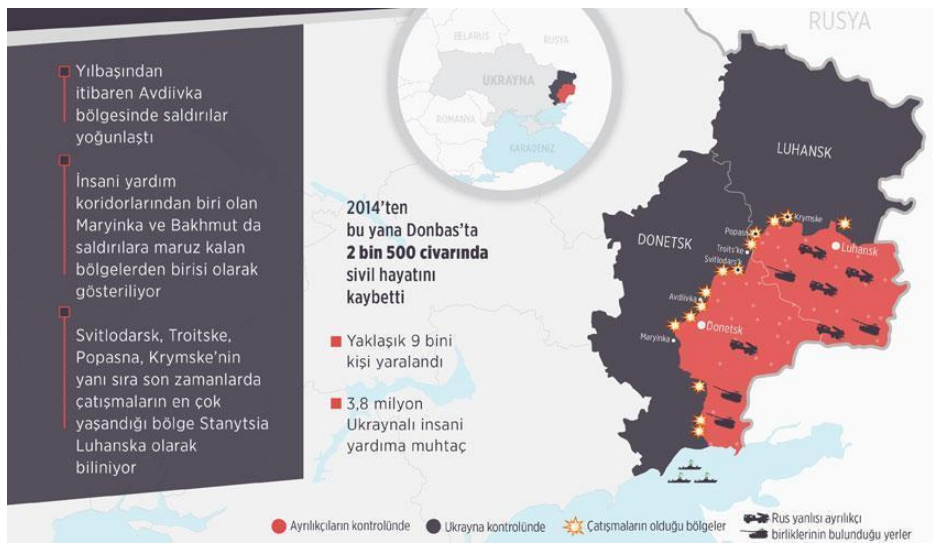

Kaynak: Anadolu Ajansı

BM Genel Sekreteri İnsan Haklarından Sorumlu Yardımcısı İvan Simonoviç'in bu toplantılarda sunduğu raporlarda genel olarak şu konulardan bahsedilmiştir:

1. Ukrayna'daki yasal düzenlemeler konusundaki olumlu gelişmeler 
2. Anayasal reformlar ve çıarılan af yasası (Memorandum of Concord and Peace- 20 Mayis)

3. Ukrayna hükümetinin yeniden ele geçirdiği yerlerde (Slovyans gibi) hayatın normale dönmesi (UN Security Council, 20141, 2)

4. Ukrayna Hükümetinin genel af yasasının belli suçları (soykırım, terörizm, katletme, ağır yaralama, rehin alma, insan kaçakçılı̆̆1, cinsel istismar) işleyenleri kapsamaması gerekliliği (UN Security Council, 2014h, 5)

5. 25 Mayıs seçimleri ve Doğu bölgelerinde seçimlerin engellenmesi

6. Euro-Maidan olaylanı ve 2 Mayıs Odesa olay $1^{3}$ esnasında yaşamını kaybeden kişilerin sorumluları ile ilgili hukuki sürecin başlatılması ve safhalar1

7. Hayatını kaybeden insanlar ve bunun önlenememesi

8. Bulunan cesetlerin tanımlanması, ailelerine teslimi ve insan onuruna yakışır şekilde defnedilmeleri

9. Rusya Federasyonu, Çeçenistan ve Kuzey Kafkasya'dan silahlı grupların varllğ1

10. Silahlı grupların ağır silahlara (misket bombası gibi) sahip olması

11. Kaçırılma, alıkoyma, kaybolma vakalarındaki artış

12. Hükümetin güç kullanmada dengeli olma gerekliliği

13. Çocukların durumu, silahlı grupların kontrolündeki bölgelerde doğan çocukların Ukrayna tarafindan vatandaş sayılmaması ve bu çocukların devletsiz kalma durumuyla karşı karşıya olmaları

14. Yaşanan yiyecek, ilaç ve su sıkıntısı

15. Gazetecilerin karşılaştıklan tehlikeler ve ifade özgürlüğü

16. BM İnsan Hakları Yüksek Komiserliği’nin yaptığı olumlu katkılar (Suçsuz tutukluların salıverilmesi, )

17. Muhtemel haciz ve zarar verilmiş, el konulmuş ve yağmalanmış ev sahiplerine telafi edici hiçbir mekanizmanın olmaması da dahil olmak üzere konut, arazi ve mülkiyet haklarına ilişkin sıkıntılar (UN Security Council, 2015c, 4)

32 Mayıs 2014'de kimliği belirsiz kişiler tarafından Sendika Binası'nda çıkarılan yangında 42 kişi hayatını kaybetti, 300 kişi de yaralandı. (Ukraine Today, 2015) 
18. Yerlerinden edilmiş insanlar (Internally Displaced persons) (Kaydedilenlerin sayısı 6 Mart 2015 itibariyle 1,1 milyon kişiye ulaşmıştır. (UN Security Council, 2015a, 3)

19. Kırım'daki yasal karışıklık

20. Kırım Tatarlarının durumu, Kırım Tatar Meclis Başkan yardımcısı Ahmet Ciygöz'ün tutukluluk halinin devamı, Kırım Tatarlarının liderleri Mustafa Jemilev ve Refat Çubarov hakkında bulunan giriş yasağı.

21. Rusya'nın raporların tek taraflı yazıldığına ilişkin iddiaları (UN Security Council, 2014ğ, 3-5)

2015 yllı sonunda Aralık ayı toplantısında İvan Simonoviç dokuz noktayla bundan sonra yapılması gerekenleri sıralamıştır: Tutukluların salıverilmesi, hareket özgürlüğü kapsamında Ukrayna’nın uyguladığ1 kısıtlamaları tekrar gözden geçirmesi ve silahlı grupların kontrolü altındaki bölgelerdeki değişiklikleri (ölüm, doğum, evlilik) kaydetmesi, emekli maaş ödemelerinin yapılması, Kırım'da uluslararası gözlemcilere izin verilmesi, adil yargilanmasının tesis edilmesi, ölüm ve kayıp olaylarının faillerinin soruşturulmasını, Tatarlara barışçıl toplanma, ifade ve din özgürlügünün sağlanması, kültürel ve dillerini kullanmalarına yönelik hakların tanınması. (UN Security Council, 2015c, 6)

BM İnsani İşler Koordinasyon Ofisi (OCHA) Direktörü John Ging de Ukrayna'daki insani durumun ne kadar acil olduğunu konusunda Güvenlik Konseyi'ni bilgilendirmiştir. Kendisinin verdiği bilgilere göre 1.1 milyon insan yerlerinden olmuş, 670.000 kişi komşu ülkelere kaçııs, 2 milyon kişi çatışma alanlarında yaşamakta olduğunu ve 5 milyon insanın da insani yardıma muhtaç durumda olduğunu bildirmiştir. (UN Security Council, 2015a, 3) BM İnsani İşler Koordinasyon Ofisi alt1 yerde bulunduğunu, 2,6 milyon kişiye sağlık sektöründe destek olduklarını ve (19 Şubat 2015'de) 62 ton insani yardım ulaştırdıklarını iletmiş̧ir. Ateşkes yürürlüğe kondukça, daha geniş kitlelere ulaşılmış ve Güvenlik Konseyi gündemine bu yardımların finanse edilmesi meselesini de gündeme alarak, 221 milyon dolar kullanılacağı belirtilerek finansman için üyelere çağrıda bulunulmuştur. (UN Security Council, 2015b, 3) Aralık 2015 ayındaki toplantıda ise Hükümetin kontrolü dışındaki Luhansk ve Donetsk'deki otoritelerin uluslararası insani yardım amaçlı kuruluşların girişlerini engelledikleri hususunu dile getirmiştir.

Haziran ve Temmuz 2015 görüşmelerinden sonra Aralık 2015, Mart ve Nisan 2016 tarihlerinde de görüşmeler yapılmıştır. Aralık ayındaki görüşmelerde Ivan Simonovic, Ukrayna'daki insani durumla ilgili olarak düşmanlıkların gittikçe azaldığını ancak halen bombardıman ya da mayın yüzünden ölen sivillerin olduğunu ve ölü sayısının toplamda 9,115 kişiye ulaştığını ifade etmektedir. (UN Security Council, 2015c, 4) Nisan ayındaki 
toplantıda bu sayı 9,300 ölü ve 214,000 yaralı olarak ifade edilmiştir. (UN Security Council, 2016, 2) Diğer önemli sorunlardan diğerinin de kayıp insanlar olduğu ve sayılarının 3000'ni bulduğu belirtilmiştir. (UN Security Council, 2015c, 4)

Doğuda, Luhansk ve Donetsk yönetimindeki bölgelerde ise insan haklar1 ihlallerinin yaşandığ1 ve özellikle tutukluların içinde bulundukları zor durumdan bahsedilmiştir. Ayrıca yerleşim yerlerindeki halk da sağllk hizmetleri, barınma gibi ihtiyaçların karşılanamaması, haczedilme dahil konut ve mülk haklarına yönelik ihlaller, zarar görmüş yapılarla ilgili yeterli telafi edici mekanizmaların olmaması gibi sorunlarla karşı karşıya olduklarını tekrar dile getirmiştir. (UN Security Council, 2015c, 4) Ayrıca içinde bulunulan siyasi durum sebebiyle bu bölgelerde yapılan sivil kayit belgeleri Ukrayna hükümeti tarafindan geçersiz sayllmakta, bu da insanları temel sosyal ve sağlık hizmetlerinden yararlanmalarını zorlaştırmaktadır. Ayrıca Ukrayna hükümetinin uyguladığ1 geçiş noktalarındaki sınırlamalar bölgedeki tecridi arttırmaktadır. İnsanlar geçebilmek için saatler harcamak zorunda kalmakta ve sık1 denetimden geçmektedirler. Kırım'daki insani durum ise halen aciliyetini korumaktadır (UN Security Council, 2015c, 5). Nisan ayındaki toplantıda Kırım Meclisi'nin kapatılması gündeme taşınmış, Rusya da aşırılık içeren faaliyetleri yüzünden kapatıldığını ve bunun Rusya'nın iç meselesi olduğunu söylemiştir (UN Security Council, 2016, 3 ve 22).

John Ging de Ukrayna'daki insani durumun çok acil olduğunu, de-facto hükümetlerin insani yardım örgütleri kontrol altındaki bölgelerden çıkardığını, çok azının yeniden iş başına dönebildiklerini ifade etmiş ve durumun düzeltilmesini istemiştir. Ukrayna hükümetini ise insani yardım konvoylarının geçişlerinde kolaylık sağlaması konusunda uyarmış ve su ve elektrik kesintisine ilişskin yasa tasarısının çok kötü etkileri olacağını ifade etmiştir. (UN Security Council, 2015c, 7) Tüm engellemelere rağmen BM ve diğer uluslararası sivil toplum örgütlerinin 2015'de 2,1 milyon insana temiz su, 320.000 kişiye yemek, 230.000 insana yemek dış1, 75.000 kişiye de tıbbi yardım ulaştıııldığını söylemiştir. (UN Security Council, 2015c, 7)

Bu süreçte de iki BM Güvenlik Konseyi kararı ve karar tasarısı çıkmıştır. 15 Mart 2014'te Ukrayna'nın birliğini, egemenliğini, toprak bütünlüğünü teyit eden, Ukrayna'nı 16 Mart 2014 yapılacak referandumu ve sonuçlarını tanımadığını dile getiren ve diğer ülkelere de bu sonucu tanımama ya da tanımayı sonuç verecek hiçbir eylemde bulunmamaya çağıran bir karar tasarısını görüşmüş; ancak Rusya'nın veto etmesi sebebiyle kabul edilememiştir. (UN Security Council, 2014j) Oysa BM Şartı'nın 52. Maddesinin 3. Fikrası hükümleri uyarınca "alınan kararlarda bir uyuşmazlığa taraf olan [Güvenlik Konseyi üyesi] oylamaya katılamaz." (UHDİGM, 1945, 11) Fakat Güvenlik Konseyi üyeleri bu hükmü bile uygulayamamışlar ve bu kararın Rusya ile ilgisi olmadığına hükmetmişlerdir. 
21 Temmuz 2014'de ise 2166 say1l BM GK kararıyla 17 Temmuz'da Donetsk'te Malezya Havayolları'na ait uçağın düşürülmesi kınanmış ve olayın uluslararası bir kurul tarafindan tam, derinlemesine ve bağımsızca uluslararası bir soruşturma yapılması istenmiştir. (UN Security Council, $2014 \mathrm{k}, 1-2)$

12 Şubat 2015'de “Minsk Anlaşmalarının Uygulanması için Önlem Paketi"nin kabul edilmesi üzerine, destek mesaj1 veren ve AGİT'e gözlemleme sürecinde yer verilmesini öneren 17 Şubah 2015 tarihli 2202 sayılı BM GK kararı alınmıştır. (UN Security Council, 2015d, 1)

31 Ocak 2017'de Ukrayna'daki durumun kötüleşmesi, bunun sivil halk üzerindeki etkisinde endişe ettiklerini, Minsk Ateşkesi ile yasaklanan ağr1 silahların kullanımını kınadıklarını ifade ederek; GK'nin Ukrayna'nın toprak bütünlüğü ve egemenliğini desteklediklerini ve 2202 sayılı BM GK kararına uyulması gerekliliğine vurgu yapan bir Basın Açıklaması (press statement) yayınlanmıştır. (UN Security Council, 2017b)

Görüldüğü üzere Güvenlik Konseyi BM'nin en etkin organı olmasına rağmen ne barış görüşmelerine ön ayak olabilmiş ya da sürdürebilmiş, ne BM Barış Gücü oluşturabilmiş ne de insani durumun iyileşmesi ya da insan hakları ihlallerin engellenmesi konusundaki çalışmalara bir katkıda bulunabilmiştir. Tüm görüşmeler Ukrayna temsilcisi ile ona destek olan Batılı ülke (özellikle ABD, Fransa, Birleşik Krallık, Litvanya) temsilcileri ile Rusya Federasyonu temsilcilerinin karşılıklı suçlamaları ve birbirine büyük ölçüde zit verdiği bilgilendirmelerle geçmiştir. Diğer üyelerin verdiği beyanatlar da birkaç istisna dişında diplomatik teşekkür ve kınama ya da endişelerin olduğunu ifade edilen kısa konuşmalardır.

Ukrayna konulu BMGK'ndeki görüşmeler devam ederken, 2014 y1lı boyunca 21 Şubat, 17 Nisan Cenevre, 6 Nisan ve 11 Şubat Normandi 4 (Almanya, Fransa, Rusya, Ukrayna arasında) görüşmeleri, 23 Haziran AGİT gözetiminde Donetsk görüşmeleri yapılmış, 5 Eylül Minsk I ve 12 Şubat 2015 Minsk II imzalanmış, sürekli Güvenlik Konseyi toplantılarda adları geçmiş; ancak hiç biri BMGK ya da Genel Kurul gözetiminde ya da arabuluculuğunda gerçekleştirilmemiştir. Sorunun taraflarından birinin Rusya Federasyonu olması, onun da veto hakkının bulunması her türlü faaliyet için gereken BMGK kararının çıkmasını engellemiş, Ukrayna krizinde BMGK'nın elini kolunu bağlamıştır.

\section{BM'in Diğer Organ ve Komiserlikleri}

\subsection{Genel Kurul}

Genel Kurul'da da Ukrayna konusu ele alınış ve 27 Mart 2016 tarihinde 88. Oturumunda 68/262. Genel Kurul kararı almıştır. (UN General Assembly, 2014) Bu Genel Kurul kararında öncelikli olarak BM Şartı'nın 
hukukun üstünlüğ̈ ilkesinin önemine, 2. Madde uyarınca tüm devletlerin uluslararası ilişkilerinde herhangi bir devletin toprak bütünlüğüne ya da siyasi bağımsızlığına karşı kuvvet kullanma tehdidine ya da kuvvet kullanılmasına başvurmaktan çekinme ve uyuşmazlıklarını barışçıl yollarla çözme yükümlügüne değinmiştir. Sirasıyla 24 Ekim 1970 tarihli Devletler arası BM Antlaşması Doğrultusunda Devletler Arasında Dostça İlişkiler ve İşbirliğine İlişkin Uluslararası Hukuk İlkeleri Konusundaki Bildirge’ye, 1 Ağustos 1975 tarihli Helsinki Nihai Senedi'ne ve 5 Aralık 1994 tarihli Budapeşte Bildirisi'ne, 31 Mayıs 1997 Ukrayna ve Rusya Federasyonu arasında Dostluk, İşbirliği ve Ortaklık Antlaşması'na ve 21 Aralık 1991 tarihli Alma-Ata Deklarasyonu'na dikkat çekilmiştir. Ukrayna'da halkın farklılığını yansıtacak ve tüm taraflardan temsilcilerini de dahil eden kapsayıcı siyasi diyaloğun devamının önemine vurgu yapılmış ve Genel Sekreter, AGİT ve diğer bölgesel ve uluslararası organizasyonların gerginliğin düşürülmesine yönelik çabalarını takdir edilmiştir.

Son kısımda da 16 Mart 2014 tarihli, Kırım Özerk Cumhuriyeti ve Sivastopol'de yapılan referandumun Ukrayna tarafindan onaylanmadığını ifade etmiş ve uluslararası tanınmıs sınırlar içinde Ukrayna'nın toprak bütünlüğüne, birliğine, egemenliğine ve siyasi bağımsızlığına ilişkin verilen taahhüttü yenilemiş, tüm devletleri güç kullanma ya da güç kullanma tehdit veya diğer hukuksuz yollarla Ukrayna’nın sınırlarının değiştirilmesine yönelik girişimler de dahil olmak üzere bu devletin toprak bütünlügüne ya da ulusal birliğini kısmen ya da tamamen tahrip edecek faaliyetlerden çekinme ve vazgeçmeleri çağrısında bulunmuştur. Çatışmanın tüm taraflarını acilen siyasi diyalog yoluyla barışçl yollarla çözüme davet etmiş ve gerginliği arttıracak söylemlerden ve tek taraflı eylemlerden çekinmelerini ve uluslararası uzlaşma çabalarına katılmalarını istemiştir.

Kararın dördüncü maddesinde de Ukrayna'daki insanların özellikle azınlık gruplarına mensup kişilerin haklarının korunmasına yardım etmek amacıyla çalışan tüm kuruluşları takdir etmiştir. Son maddelerinde de Kırım ve Sivastopol'da yapılan referandumun geçerliliğinin olmadığını ve Kırım Özerk Cumhuriyeti ve Sivastopol şehrinin statüsünün değiştirilmesine dayanak olamayacağını vurgulamış ve tüm devletlere, uluslararası örgütlere ve özel statülü kurumlara, bu referanduma dayanarak Kırım Özerk Cumhuriyeti ve Sivastopol şehrinin statüsünün değiştirilmesinin tanımamalarını ya da tanımayı sonuç verecek ya da tanınma şeklinde yorumlanabilecek herhangi bir bağıttan veya eylemden kaçınmaları çağrisında bulunmuştur. (UN General Assembly, 2014, 1-2)

\subsection{BM İnsan Hakları Yüksek Komiserliği}

BM İnsan Hakları Yüksek Komiserliği de olayların patlak verdiği tarihten itibaren Ukrayna'daki olayları gözlemlemiş ve Mart 2014 ayında Kiev'de 7 kişilik insan hakları yetkilileri ve 25 ulusal yetkili ile beraber bir misyon 
oluşturmuştur. Misyon merkezi Kiev'de olmasina rağmen Lviv, Odessa, Simferopol, Donetsk and Kharkiv şehirleri öncelikli çalışma alanı olarak seçilmiş̧ir. Misyonun başında da yukarıda ifade edildiği gibi Ivan Simonovic bulunmaktadır. Mali kaynak ise Genel Sekreter'in önceden öngörülemeyen ve sıra dışı olaylar için tahsis edilmiş ödeneğinden sağlanmıştır.(UN OHCHR: 1-2) Bu tarihten sonra 15 Nisan 2014'ten 8 Ekim 2014'e kadar aylık, 15 Şubat 2015'e kadar iki aylık raporlar hazırlamış, daha sonra Haziran, Ağustos, Aralık 2015 ve Mart ve Haziran 2016 tarihlerinde olmak üzere beş rapor sunmuştur.

İlk dönemde (Mart 2014 tarihinde başlayan dönem) hazırlanan raporlar yolsuzluk ve ekonomik ve sosyal hakları ihlallerinin, hukukun üstünlügü ve insan hakları ihlallerine ilişkin kurumlara yönelik güvensizlik, Maidan gösterileri esnasında ve 2 Mayıs Odesa'da yaşanan insan hakları ihlalleri ve diğer insan hakları konusunda başlatılan hukuki süreç, seçme ve seçilmeye ilişkin siyasi haklar (25 Mayıs seçimleri sırasında), azınlık hakları, ifade özgürlüğü, toplanma özgürlüğü, serbestçe bilgi alabilme özgürlüğü, din ve inanç özgürlüğü, tahrik edici söylemler, Ukrayna yönetiminin gerçekleştirdiği reformlar, anayasa değişiklikleri (UN OHCHR, 2014a: 10-22), Luhansk ve Donetsk'de binalara askerler tarafindan el konulmasi(UN OHCHR, 2014b: 21), kendi devlet sistemlerini kurmaları, Ukrayna otoritelerini tanımamaları (UN OHCHR, 2014c: 14), ülke içinde yer değiştiren insanların sayısının artması ve ihtiyaçları ve Kırım'a özgü olarak da medya ve haber alma kaynaklarına konulan kısıtlar, kaçırma, alıkonulma, hukuksuz bir şekilde tutuklanma, kaybolma, işkence, askeri birliklerin varlığı, Kırım'da Rus vatandaşlığı imkânı sunulduktan sonra kayıtlarda çıkan sorunlara, belli kamu hizmetlerine erişememe, mülk haklarına yönelik sorunlar, hareket özgürlüğüne getirilen kısıtlamalar, belirsizlik ve Kırım Tatarları'nın durumu gibi konulara değinilmiştir.

15 Haziran'da hazırlanan rapor, Ukrayna Hükümeti'nin başlattı̆ğ operasyonlarla öncelikli olarak yaşamlarını kaybeden ve yaralanan insanların durumuna dikkat çekmiştir. (UN OHCHR, 2014c: 7) Yine bu de-facto bağımsızlıklarını ilan eden cumhuriyetlerde yaşanan kaçırılma, alıkonulma, tutuklanma, işkence, öldürme gibi olaylara da yer verilmiştir. Ağustos raporunda Minsk'te gerçekleşen görüşme ve anlaşmaya da değinilmiştir. (UN OHCHR, 2014d: 4) Daha sonraki raporlarda sosyal ve ekonomik haklar başıı̆ında sosyal koruma, yeterli yaşam şartlarına haiz olma, yüksek kalitede fiziksel ve psikolojik sağlik hizmetinden yararlanma hakkı (UN OHCHR, 2015: 21), kişinin yaşamını sürdürebilmesi için fiziksel koşullara ulaşma hakkı, çalışma hakkı, çalısma ortamına ilişsin haklar, sosyal güvenlik hakkı, eğitim hakkı, kadın hakları (UN OHCHR, 2014e) gibi konulara da değinilmiştir. 
Yüksek Komiserlik temel olarak oluşturduğu özel misyon araciluğyla Ukrayna'da gözlemlerde bulunmuş ve raporlar hazırlamıştır. Bunun yanı sıra yine yüksek komiserlik çatısı altında Engelli Hakları Komitesi de 31 Ağustos 2015 tarihinde kabul edilen raporunda genel olarak engelli kişilerin hakları ile ilgili sorunlara dikkat çekerken, ayrıca çatışmalardan sonra ortaya çıkan ek sorunlara da değinmiştir (CRPD, 2015). BM İşkenceye Karşı Komite ise 1819 Kasım 2014 tarihli raporunda işkence sorununa yönelik genel değerlendirmesinin yanı sıra hem Maidan olayında, daha sonraki 2 Mayıs 2014 ve 9 Mayıs 2014 olayları esnasında işkence olaylarına değinmişsir. Aynı zamanda Donetsk ve Luhansk'ın kontrolü altındaki bölgelerde yaşanan işkenceyle alakalı sıkıntılara dikkat çekilmiştir. (Committee against Torture, 2014) Nisan 2014'de Azınlık Haklarına ilişkin ve Şubat 2014'den sonra yaşadıkları ek sıkıntılara yer veren özel rapor ve Eylül 2014'de de yerinden edilmiş kişilerin kişilerin insan hakları durumlarına ilişkin rapor ve Mayıs 2016'da Kanunla yetkili olmayanlar Kişiler yapılan keyfi tutuklamalar üzerine de üçüncü bir özel rapor hazırlanmıştır. (UN OHCHR, 2016)

\subsection{Birleşmiş Milletler Mülteciler Yüksek Komiserliği}

Ukrayna'daki Birleşmiş Milletler Mülteciler Yüksek Komiserliği (BMMYK) ilk olarak 1994'de Ukrayna'ya gelmiş ve Ukrayna'nın 2002'de 1951 Mültecilerin Statüsüne İlişkin Protokolü ve ilgili ekleri imzalamasından sonra, Komisyon işlevine başlamıştır. Temel olarak BMMYK Hükümete mültecilerin korunması, gerekli yasaların çıkması, sığınmacı için sistemin kurulması, hükümet görevlilerinin bilgilendirilmesi gibi konularda yardım etmekte ve tavsiyelerde bulunmakla beraber ülkenin mültecilerin korumasına ilişkin uluslararası yükümlülüklerini yerine getirip getirmediğini de gözlemlemektedir. (UNCHR)

Ukrayna'daki kriz esnasında Yüksek Komiserlik, komşu ülkelere göç eden mültecilerin durumunu da gözetmiştir. Mülteci statüsü veren ülkelerin hükümet kaynaklarına göre komşu ülkelerde iltica talebinde bulunan ya da diğer şekillerde yasal kalma hakk1 tanınan kişi sayısı; çoğunluğu Rusya Federasyonu ve Beyaz Rusya'da olmak üzere, 1,4 milyon insana ulaşmıştır. Temmuz 2016 itibariyle Avrupa Birliği ya da komşu ülkelere 7967'si Almanya'ya olmak üzere toplamda 26922 kişi uluslararası koruma için başvurmuşlardır. (UNHCR Operational Update, 2016b, 2)

Ukrayna'da ise 2014'deki krizden sonra temel olarak yerinden edilmiş insanlara yönelik yardımlarda bulunmak üzere Dnipro, Donetsk, Kharkiv, Luhansk, Mariupol ve Sievierodonetsk'de altı ofis kurmuştur. Mayıs 2016 itibariyle 24’ü uluslararası 107 ulusal personelle çalışmaktadır.

Yerinden edilmiş insanlarla ilgili olarak BMMYK en zor durumda olan kişilere doğrudan yardım etse de asıl olarak Ukrayna hükümetine ve sivil toplum örgütlerine yardım etmektedir. Sağladığı teknik destek hizmetinin 
yanı sıra, sivil toplum örgütleri Crimean Development Fund (Crimea SOS), Right to Protect ve diğer yerel sivil toplum örgütlerine yasal danışmanlık ağının kurulması, kapasite artırtılması ve sosyal yardım düzenlemeleri konularında yardım etmektedir. National Society of the Red Cross in Ukraine aracılı̆̆ıyla 5000 kişiye yemek dışı ve ek gida yardımı ulaştırmışıır. (UNCHR, 2015)

Hükümet yetkilileri ile gerekli yasaların çıkması, bu sayede mültecilerin ve yerinden edilmiş insanların korunmaları ve diğer ihtiyaçları için gerekli yasal zeminin teminine yardım etmektedir. Örneğin 2015'de Ulusal İnsan Hakları Programının kabul edilmesi, Kadına Yönelik Şiddetin Önlenmesine İlişkin Hareket Planının oluşturulması, Yerinden edilmiş kişilerin kayıt ve sosyal yardıma ulaşmalarına ilişkin mevzuatın iyileştirilmesi, İnsani Yardım kanunun değiştirilmesi gibi konularda BMMYK hükümete destek ve yardımcı olmuştur. (UNCHR Ukraine, 2015: 1)

\section{Harita 1: Ukrayna'da Yerinden Edilmiş İnsanlar ve Mülteciler (OCHA, 2015)}

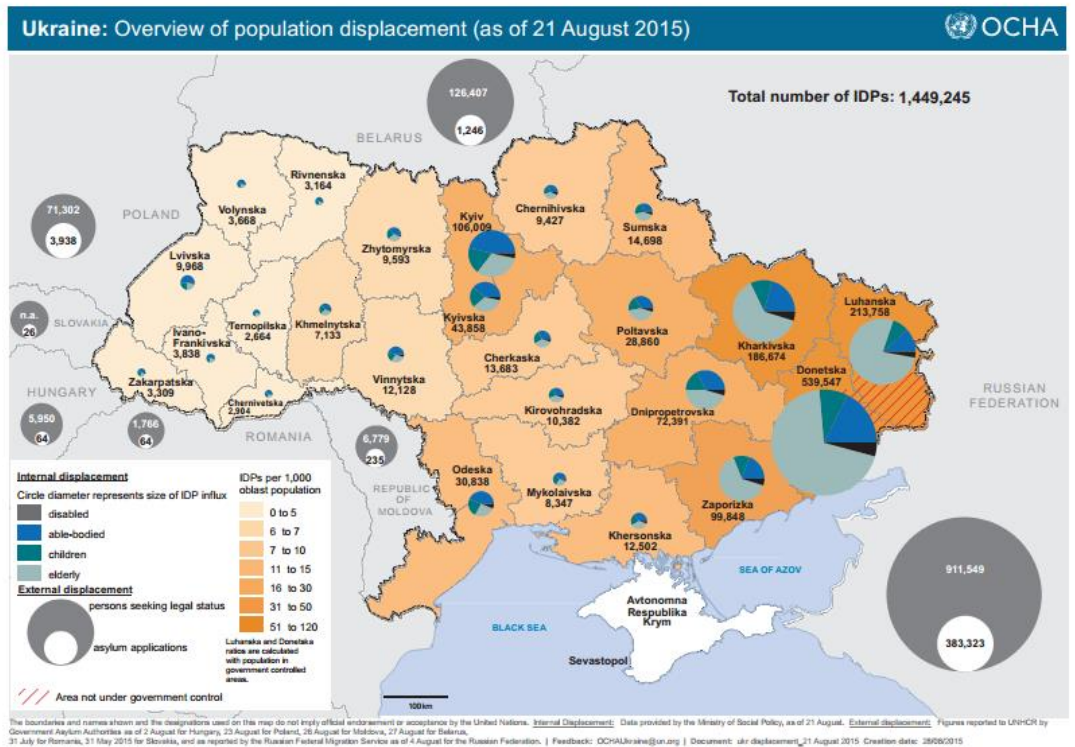

Ocak 2016'ya kadar; 24.700 battaniye, 25.000 yatak örtüsü, 7.000 havlu, 6.800 kıyafet, 2.200 mutfak eşyaları ve 8.200 yiyecek paketleriyle 50.000 'den fazla insana yardım ulaştırmıştır. Evlerine tamir etmek isteyen insanlara da inşaat malzemeleri, ısınma ve mobilya yardımı da yapmıştır (2015'de 11.962 hane halk1 (UNCHR Ukraine, 2015: 2). Lviv, Kyiv, Dnipropetrovsk, Zakarpattia, Odesa, Kherson, Chernihiv, Cherkasy, Kirovohrad, 
Zaporizhzhia and Vinnitsa'da 4.637 aileye / 11,833 kişiye doğrudan para yardımı temin etmiştir. Ayrıca temel temizlik malzemeleri, barınma merkezlerine kışa hazırlık için gerekli malzemeler (yakıt, kalın giyecek, kışlık ayakkabı ve 1sıtıcı temini gibi), evlerin tamiri için kaplamalar gibi ayni ve ( üç ya da üçten fazla çocuklu ailelere, engellilere, hamile kadınlara ve tek ebeveyne olmak üzere sadece 2015'de 8.116 kişiye (UNCHR Ukraine, 2015: 2) nakdi yardım ulaştırmışır. (UNCHR, 2015) Sadece 2015'de 6,6 milyon dolar kışa hazırlık yardım paketi (winterization assitance package) çerçevesinde 48.240 kişiye ulaşılarak harcanmıştır. (UNCHR Ukraine, 2015: 2)

$\mathrm{Bu}$ tarz yardımların dışında danışma hizmeti ve psikolojik destek hizmetleri de vermektedir. "Şahsi Koruma Yardımı" (Individual Protection Assistance) şeklinde de özel ve acil yardıma muhtaçsa kişiye (engelliler, çıkarılma tehlikesine maruz kişiler, acil hastalar) özel koruma sağlamaktadır (2015'de 1.342 olay) (UNCHR Ukraine, 2015: 2). Ayrıca "Hızlı Etki Projeleri”" (Quick Impact Projects) denilen, içme sularının iyileştirilmesi, hastanelerin yeniden yapılandırılması, yurtların ve çocuk bahçelerinin yenilenmesi ve barış içinde beraber yaşam ve yerinden edişmiş kişilere yönelik hoşgörü üzerine kamu bilincinin arttırlması gibi projenin yürütüldügü yerdeki halkın yaşamlarının çeşitli yönlerini iyileştirmeye yönelik çalışmalar da yapılmıştır. (UNCHR Ukraine, 2015: 2)

\section{Harita 2: Doğu Ukrayna'daki Hızlı Etki Proje Yerleri ve Türleri}

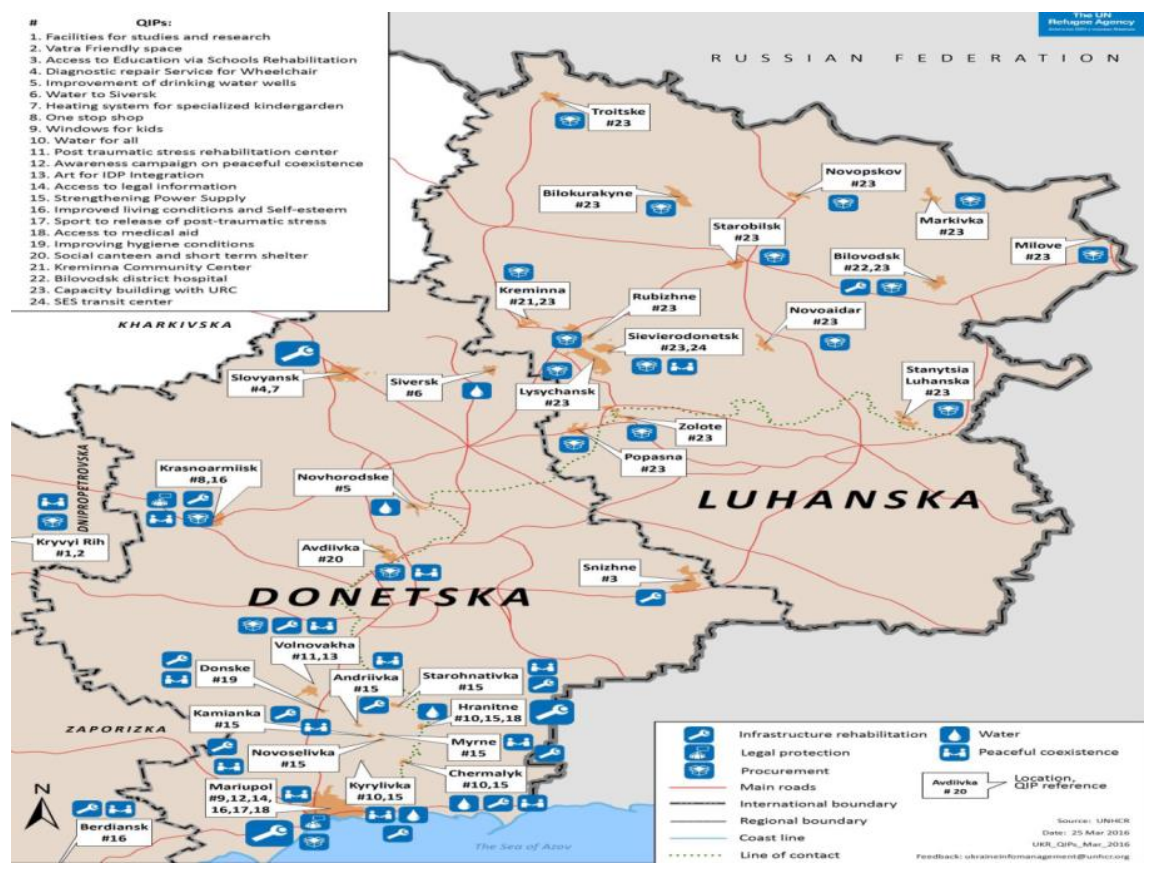


Kaynak: Doğu Ukrayna Hızlı Etki Projeleri, 2015. (UNHCR, 2015: 2)

Bir tanesi hükümetin kontrol ettiği bölgenin dışındaki yerlerde olmak üzere 24 proje yürütülmekte olup, 1 milyon kişinin yararlandığ 1 bu projelerde 233.000 dolar harcanmaktadır. (UNHCR, 2015: 1)

BMMYK'nin çalışma yaptığı bir diğer alan da cinsel şiddetin ve kadına yönelik şiddetin önlenmesi olup, psikolojik destek ve yasal yardım, bilincin arttırılması, psiko-sosyal, tıbbi, yasal ve güvenlik yardımı sağlanması, bu konuda çalışan resmi ve sivil kuruluşların kapasitelerinin artırılması, İstanbul Protokolünün ${ }^{4}$ onaylanması, geçici sığınakların kurulması gibi faaliyetlerde bulunmaktadır. (UNCHR, 2016: 4) Bu çerçevede BMMYK, bu konuda çalıșan "Zor Durumdaki Aileler için Kriz Merkezi”" (Kiev), Anne ve Çocuk Merkezi (Chernivtsi), "Bir Çocuğun Gülümsemesi" (Zaporizhzhia), "Yeni Binyll" (Mykolaiv ve Pervomaisk) ve "Slavyane" gibi sivil toplum örgütlerine şiddet mağdurlarına destek veren ya da şiddeti engellemeyi amaçlayan projeler vasitasiyla yardım etmektedir. (UNCHR, 2016: 2-3)

\section{Harita 3: Ukrayna'da BM Mülteciler Yüksek Komiserliği}

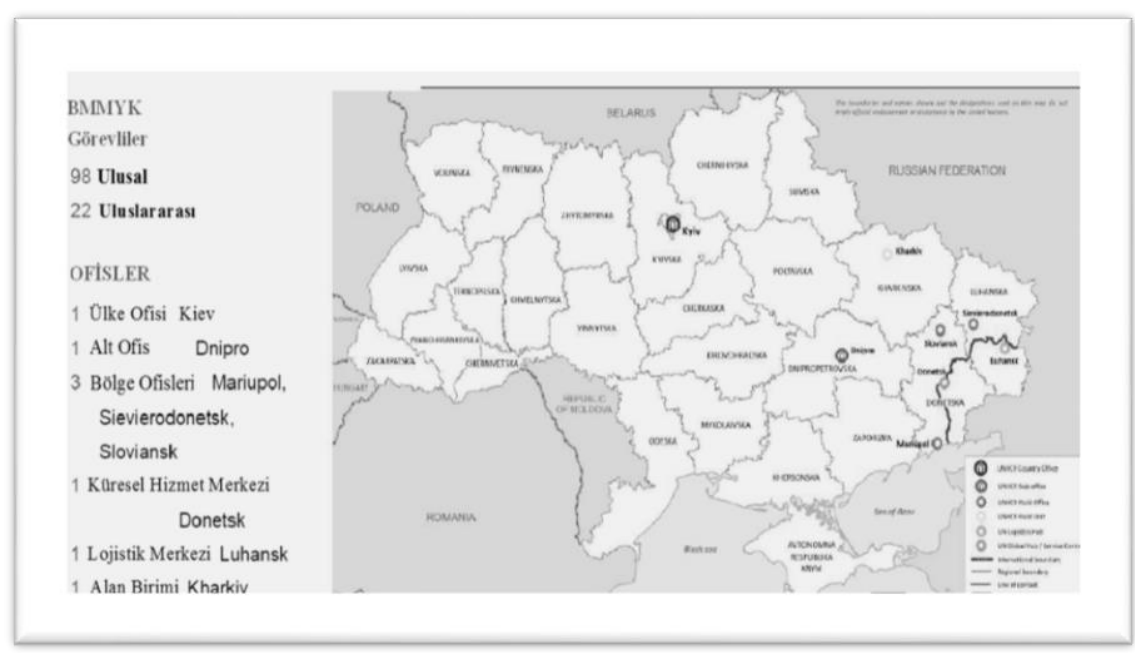

Kaynak: BM Mülteciler Yüksek Komiserliği Raporu (UNCHR, 2017, 1)

Ayrica, koordinasyonun ve daha iyi savunma amaciyla BMMYK Koruma Birimi altında Cinsel Şiddetin ve Kadına Yönelik Şiddetin Önlenmesi alt birimi Kyiv, Dnipropetrovsk, Zaporizhzhia, Kharkiv, Sievierodonetsk and Kramatorsk şehirlerinde kurulmuştur. (UNCHR, 2016: 4) Aslinda pek çok BM MYK faaliyetlerinde öncelikli olarak bu kadınlara yardım edilmekte

\footnotetext{
${ }^{4}$ Kadınlara Yönelik Şiddet ve Aile İçi Şiddetin Önlenmesi ve Bunlarla Mücadeleye İlişkin Avrupa Konseyi Sözleşmesi (the Convention on Preventing and Combating Violence against Women and Domestic violence) (2011) İstanbul Protokolü olarak bilinmektedir.
} 
(para ve yasal yardımda) ve yukarıda bahsedilen "Şahsi Koruma Yardımı" öncelikle bu kişiler gözetilmektedir. (UNCHR, 2016a: 1)

\section{Şekil 2: "Benim Evim Nerede" Yazılı Poster (UNCHR, 2015: 3)}

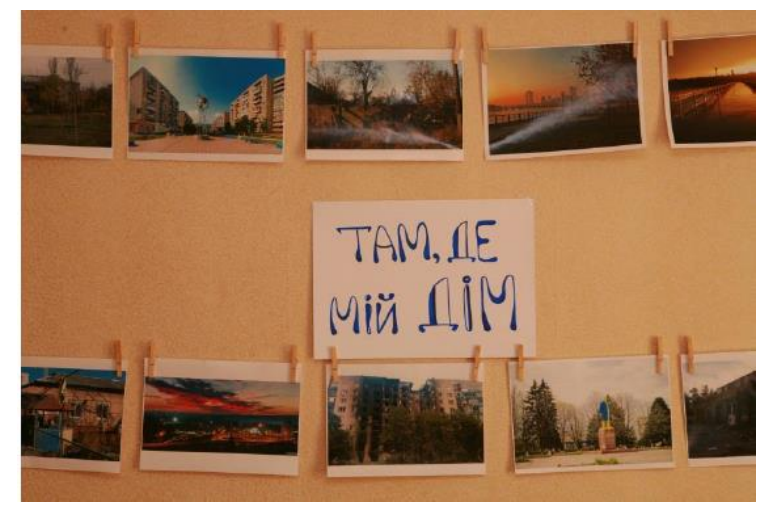

Hızlı Etki Projeleri kapsamında Kryvyi Rih Şehri'nde (Dnipropetrovsk) açılan Vatra Dostluk Mekanı'ndaki (Vatra Friendly Space) bir poster. (UNCHR, 2015: 3)

BMMYK yerinden edilmiş insanlarla ilgili çalışmalanı için gerekli fonu 37,7 milyon dolar olarak belirlemişse de bunun ancak \%35'nin bağışlardan karşılayabilmiş olup( UNCHR, 2017), bağış verenler Kanada, Estonya, AB, Almanya, Japonya, Rusya Federasyonu, İşveç ve özel kuruluşlardan oluşmaktadır. (UNCHR, 2016b: 1-2)

\subsection{Birleşmiş Milletler Kalkınma Programı}

Krizin çıktı̆̆1 tarihten sonra yaşanan süreçte rol alan Birleşmiş Milletler Kalkınma Programı (BMKP) (UNDP) için öncelikli ilgilendiği alanlar yerinden edilmiş kişiler ve onların insani ihtiyaçları ve çatışmanın etkilediği alanlarda İyileşme ve Barışın tesis edilmesi süreçleri olmuştur. BMKP İyileşme ve Barışın Tesisi programı çerçevesinde hayati öneme sahip sosyal ve ekonomik altyapının tamirinde, Doğu Ukrayna'daki yerel yönetimlerin etkin çalışmasında, yerinden edilmiş insanlar ve gittikleri yerdeki halk arasında girişimciliğin teşvikinde ve iş imkânları oluşturulmasında ve barış ve uzlaşmanın desteklenmesinde yardımcı olmaya çalışmaktadır. (UNDPa) Halihazırda yürütülen otuz projenin içinde hususi olarak Ukrayna'daki son krizle alakalı olarak "Donbas Bölgesi'nin Ekonomik ve Sosyal Durumun İyileştrilmesi/Onarımı Projesi” (\$5.000.000 bütçeli, Mart 2015-Şubat 2016 tarihleri arasında); "Ukrayna Sağlık Bakanlı̆̆1 Tedarik Hizmetlerini Destekleme Projesi” (Ekim 2015 ve Aralık 2019 tarihleri arasında, ilaç ve tıbbi malzemenin sağlanması konusunda), "Ukrayna'da yerinden edilmiş İnsanlar'ın Sosyal ve Ekonomik Sorunlarına Acil Çözüm Projesi” (Ağustos 
2014 ve Şubat 2016 tarihleri arasında, $\$ 10.020 .000$ bütçeli) olmak üzere üç proje yürütmektedir. (UNDPb)

\subsection{Birleşmiş Milletler Çatısı Altındaki Diğer Program ve Fonlar}

Ukrayna'da yukarıda detaylı olarak incelenenlerin yanı sıra Ukrayna'nın çağrısı üzerine bu ülkeye gelen BM çatısı altında faaliyet gösteren 17 fon, program ve özel birimler bulunmakta ve politika tavsiyeleri, teknik destek ve acil durum yardımında bulunmaktadır. (United Nations Ukraine) Ukrayna'nın özellikle öncelik verdiği 3 acil alanda yardımlarını yoğunlaştırmaktadır: çatışmadan etkilenen bölgelerde ve yerinden edilmiş insanlar için insani yardım, geri kazanma, istikrar ve barış inşa süreci, ve hukukun üstünlüğü ve sosyal istikrar ve demokratik yönetimin kuvvetlenmesi için uzun dönemli ülke çapında reform ve kalkınma. (United Nations Ukraine)

BM'nin yanı sıra Ukrayna'da yardım için faaliyet gösteren ulusal ve uluslararası sivil toplum örgütleri, insani yarım faaliyeti gösteren pek çok uluslararası örgüt ve sayısız gönüllüler bulunmaktadır ve bunun koordinasyonu için aralık 2014'de Grup sistemi hayata geçirilmiş ve insani yardım faaliyeti ile alakalı sekiz grup (Koruma, Sağlık ve Gıda, Sığınak ve Yiyecek Dışı İhtiyaç Maddeleri, Gıda Güvenliği, Eğitim, YIKA kısaltması ile su, temizlik ve hijyen (WASH), Geçim ve Geri Kazanım, Lojistik) oluşturulmuştur. (UN OCHA, 2016a: 1) Bu gruplar, 2N1K (Kim, Nerede ne yapıyor) sistemi her bölgede faaliyet gösteren ortakları bulmaktadır. Temmuz 2015'den bu yana hükümetin kontrolü dışındaki bölgelerde de facto yönetimin koyduğu engellemelerle bir kesinti olsa $\mathrm{da}^{5}$ şu an tüm Ukrayna'da halihazırda devam eden projelerde faaliyet gösteren 159 partner bulunmaktadır. (UN OCHA, 2016a: 1)

\footnotetext{
${ }^{5}$ Bu kesinti Donetsk'te halen devam etmektedir, Luhansk'ta Kasım 2015'de yeniden yardıma başlanmıştır. (UN OCHA, 2016b: 7)
} 
Şekil-3: Ukrayna'da Partner Sayısı (UN OCHA, 2016a: 1)

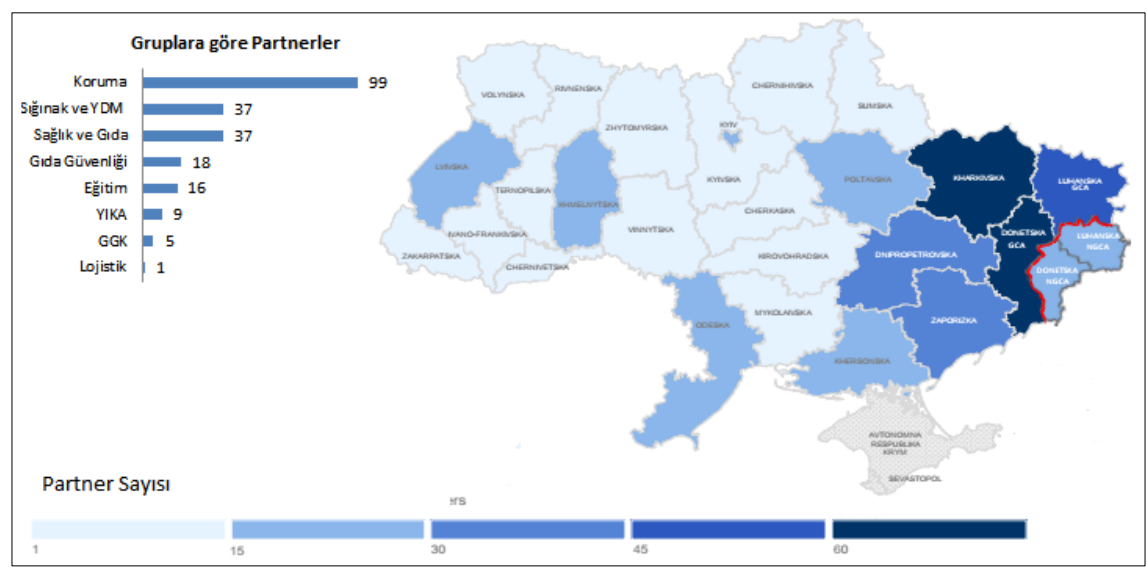

BM İnsani İşler Koordinasyon Ofisi'nin raporuna göre 2015'de ihtiyaç içindeki pek çok insana ulaşabilmiştir. (UN OCHA, 2016c: 1) 2015 yll sonu itibariyle 174 milyon dolar bağış olarak toplamıştır. Hazırlanan insani yardım planına göre halen ulaşılması gereken rakam 316 milyon dolar olup, ihtiyaç içindeki 3.2 milyon insana ulaşılması hedeflenmiştir. (UN OCHA, 2016c: 1) Bu plan çerçevesinde 2015 yıl sonu itibariyle 50.000 çocuk eğitim imkânı ve psikolojik destek sunulmuş, 187.000 çocuğa eğitim malzemeleri, 613.000 kişiye yemek ve mali yardım, 580.000 kişiye yemek yardımı ve 8.200 kişiye de acil tarım yardımı temin edilmiştir. (UN OCHA, 2016c: 1) 165.000 hastaya mobil muayene hizmeti sunulmuş, 135.000 kişiye altyapı tamiri için 7000 kişiye de iş bulmaları ya da gelirlerin arttıracak faaliyetler için yardım edilmiştir. (UN OCHA, 2016c: 1) 282.000 kişiye yiyecek dışı malzeme, 6.500 aileye katı yakıt, 63.000 aileye kışa hazırlık ve 21.000 aileye de konut onarım malzemesi temin edilmiştir. 1.6 milyon kişiye temiz içme suyu sağlanmıs, 102.000 kişiye acil su kamyonları ile ulaşılmış, 170.000 kişiye de temizlik malzemeleri dağıtılmışır. (UN OCHA, 2016c: 1) 


\section{Şekil 4: 2015 İnsani Yardım Planı'na Mali Destek Sağlayan Ülkeler ${ }^{6}$ (OCHA, 2016c: 1)}

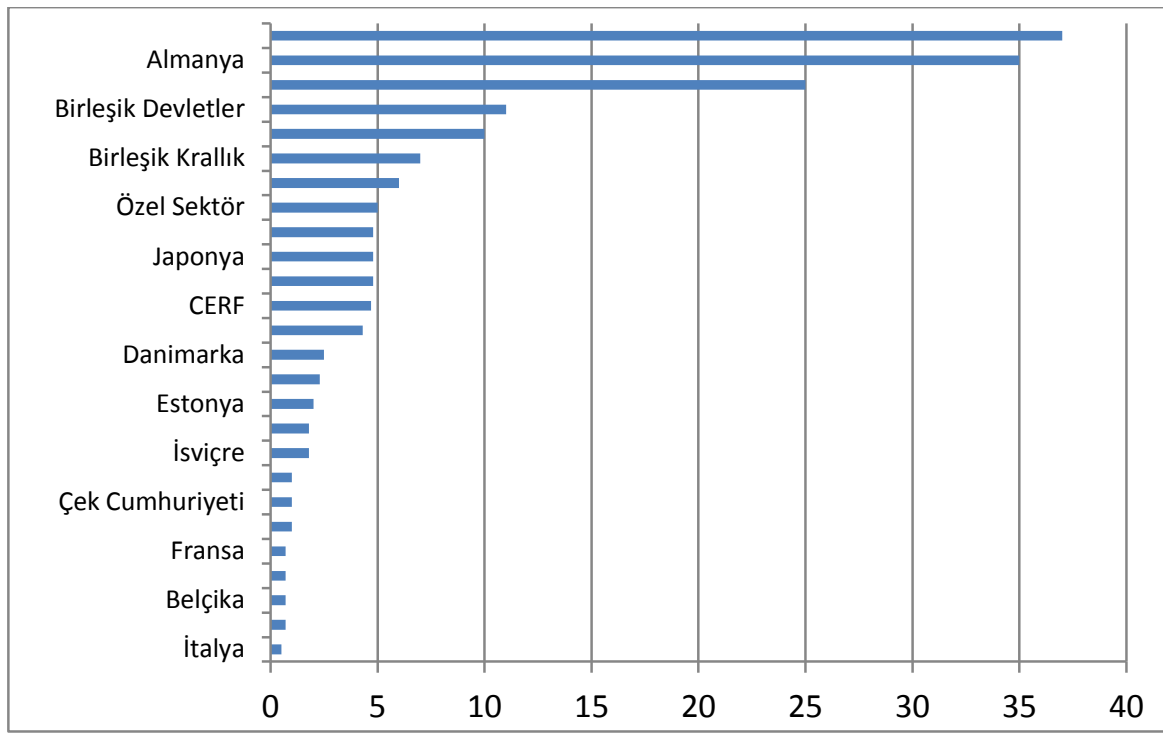

En son yayınlanan İnsani Yardım Eylem Planı 2016'ya göre de Ukrayna'da halen 3,1 milyon yardıma muhtaç insan bulunmakta, bunların \%56'sını kadınlar, \%16'sını çocuklar ve \%27'sini yaşlı kişiler oluşturmaktadır. 2016 yılı planında hedeflenen 2,5 milyon kişiye yardım sağlamak için 298 milyon dolar bütçe belirtilmiştir. Temel olarak çatışmadan etkilenen insanların korunması, acil ihtiyaçların temini ve durumlarının iyileşmesini sağlamak olmak üzere üç temel hedef belirlenmiştir. (UN OCHA, 2016b: 5) 2017 yll yarıyıl raporunda ise yardıma muhtaç insan sayıs1 4 milyona yükselmişken, 2,4 milyon insana yardım etmek hedeflenmekte, bunun için de 204 milyon dolarlık bütçeye ihtiyaç duyulduğu ve sadece 45 milyonluk bir kısmının karşılandığı belirtilmektedir. (OCHA, 2017: 4)

Görüldüğü üzere 2015'de yarıma ihtiyaç duyan kişi sayısı 5 milyon olup, 3.2 milyon kişi hedeflenmişken; 2016'da yarıma ihtiyaç duyan kişi sayısı 3.1 milyon insana inmiş, 2.5 milyon kişi hedefe alınmıştır. 2017'de tekrar 4 milyona çıkmış fakat 2,4 milyon insana yardım ulaştırmak hedeflenmektedir. Bu duruma rağmen, özellikle resmi hükümetin kontrolü altında olmayan bölgelerdeki insanların bir kısmı yardımlardan tamamen mahrumken, zor durumdaki insanlar için kalıcı ve istikrarlı bir düzenin tesisi ve bu düzen içerisinde yaşam koşullarının iyileştirilmesi için yapılan tüm bu yardımlar

\footnotetext{
${ }^{6}$ CERF: (Central Emergency Response Fund) BM İnsani İşler Koordinasyon Ofisi'nin altında oluşturulan Merkezi Acil Yardım Fonu. (UN OCHA, 2016c: 1)
} 
yeterli olmaktan çok uzakta ve bir barış anlaşması olmadan da gerçekleşmesi imkânsız görünmektedir.

\section{Sonuç}

Ukrayna krizi pek çok yazar tarafindan da belirtildiği üzere Soğuk Savaş sonrası dönemin en önemli olaylarından biri olup, Kosova, Gürcistan ile beraber Doğu Avrupa'da üçlü bir kriz zinciri oluşturmuştur. Böyle bir durum karşısında BM'nin kayıtsız kalması beklenemezken, taraflardan birinin Rusya olması BMGK'nin hareket alanını sınırlamıştır. Minsk I ve II isimli ateşkesler de AGİT çatısı altında gerçekleştirilmiştir. Bu açıdan Güvenlik Konseyi kendi yetki alanına giren bir konuda tamamen sürecin dışında kalmış ve BM Güvenlik Konseyi'nin yetersizliğini gözler önüne sermiştir. Özellikle Genel Kurul da kabul edilen kararın bir benzerinin Güvenlik Konseyi'nce veto edilerek kabul edilmemesi Genel Kurul üyelerinin Güvenlik Konseyi'nin kararlarını kabul etme ve uygulama konusundaki 25. Maddesinin Güvenlik Konseyi'ne öncelik vermesinin ne kadar sıkıntılı olduğu da gözler önüne sermiştir. Barış ve güvenliği korumakla sorumlu Güvenlik Konseyi üyelerinin kendilerinin uluslararas1 barış ve güvenliği tehdit ettiklerinde düzen ve barışın nasıl sağlanacağı da $\mathrm{BM}$ sistemi ve garantisinin diğer bir sorunudur.

Güvenlik Konseyi ve Genel Kurul dışındaki BM program ve fonları ise yukarıda belirtildiği üzere çatışmalar önlenemeyince devreye girmişlerdir. BM İnsan Hakları Yüksek Komiserliği hazırladıkları raporlarla insan hakları ihlallerine dikkat çekmiştir. Birleşmiş Milletler Mülteciler Yüksek Komiserliği bu süreçte en önemli rollerden birini üstlenmiş, yerlerinden edilmiş ve başka ülkelere giden insanlar için pek çok proje ve yardım kampanyası düzenlemiştir. Birleşmiş Milletler Kalkınma Programı da yerinden edilmiş kişiler ve onların insani ihtiyaçları ve çatışmanın etkilediği alanlarda İyileşme ve Barışın tesis edilmesi programını başlatmıştır. BM'nin yanı sıra Ukrayna'da yardım için faaliyet gösteren ulusal ve uluslararası sivil toplum örgütleri, insani yardım faaliyeti gösteren pek çok uluslararası örgüt ve sayısız gönüllüler koordinasyonu için BM İnsani İşler Koordinasyon Ofisi görev yapmiştır.

Tüm bu faaliyet ve programlar yaşadıkları yerleri terk eden, iltica eden veya çatışma bölgelerinde kalan insanlar için devasa boyutlarda çalışmalar yapmış ve milyonlarca insana yardım etmişlerdir. Ukrayna'da zor durumda olan insanlara ulaşmışlar, yaşadıkları sıkıntılara dikkat çekilmesinde ve biraz da olsa hayat koşullarını düzeltebilmelerinde diğer insani yardım kuruluşları ile beraber kısmen başarılı olmuşlardır. Ancak BM’nin öncelikli görevi yıkıldıktan sonra tamir etmek değil, bu yıkıma yol açabilecek çatışma sürecinin baştan tıkamaktır. Çatışmalar tırmanmadan önce bu sorun gündemine gelmesine rağmen bu konuda başarılı olamamış ve hiçbir suçu olamayan insanlar bunun faturasını ödemek zorunda kalmışlardır. 


\section{Kaynakça}

Allison, R. (2014). "Russian Deniable Intervention in Ukraine: How and Why Russia Broke the Rules", International Affairs, 90 (6): 12551297.

Cura, A. (2017). "Ukrayna Krizinde Diplomasi Yetersiz Kald1", Anadolu Ajansi, http://aa.com.tr/tr/turkiye/ukrayna-krizinde-diplomasiyetersiz-kaldi/890173 (erişim tarihi: 20.11.2017)

Dilek, M. S., (2015). "Rusya Federasyonu'nun Kirım Hamlesine Analitik Bakış", Turkish Studies, 10 (14): 245-272.

Gowan, R. (2015). "Bursting the UN Bubble: How to Counter Russia in the Security Council", European Council of Foreign Relations Policy Brief, June 2015.

Guiliani, J.-D. (2015). "Russia, Ukraine and International Law", European Issues, Foundation of Robert Schuman Policy Paper, No: 344.

Karabulut, B. (2015). "Birleşmiş Milletler'in Küresel Güvenlikteki Rolü ve Çevre Güvenliği Bağlamında Karadeniz Havzasındaki Faaliyetleri", Karadeniz, Arasttrmalar, 48: 43-58.

Uluslararası Hukuk ve Dış İlişkiler Genel Müdürlügü (UHDİGM), Birleşmis Milletler Antlasmasi, 26 Haziran 1946, http://www.uhdigm.adalet.gov.tr/sozlesmeler/coktaraflisoz/bm/ bm_01.pdf, erişim tarihi: (07.09.2016)

UN What's in Blue, Insights on the Work of the UN Security Council, (2016), "Briefing on the Political Situation in Ukraine", 27 April 2016, http://www.whatsinblue.org/2016/04/briefing-on-thepolitical-situation-in-ukraine.php (erişim tarihi: 05.08.2016)

UN General Assembly (2014). Resolution Adopted by the General Assembly on 27 March 2014, 68/262. Territorial Integrity of Ukraine, 1 April 2014. http://www.securitycouncilreport.org/atf/cf/\%7B65BFCF9B6D27-4E9C-8CD3-CF6E4FF96FF9\%7D/a_res_68_262.pdf (erişim tarihi: 09.08.2016)

Ukraine Today, "Odesa May: What Really Happenned- Watch on Ukraine Today", 2 May 2015, http://uatoday.tv/society/odesa-may-2watch-on-ukraine-today-424573.html, (erişim tarihi: 01.04.23016)

UN Office of the United Nations High Commissioner for Human Rights OHCHR, "Concept Note UN Human Rights Monitoring in Ukraine": http://www.ohchr.org/EN/Countries/ENACARegion/Pages/U AReports.aspx, (erişim tarihi: 10.08.2016) 
UN Office of the United Nations High Commissioner for Human Rights OHCHR (2014a), "Report on the Human Rights Situation in Ukraine”, 15 April 2014: 10-20 ve 20-22. http://www.ohchr.org/EN/Countries/ENACARegion/Pages/U AReports.aspx (erişim tarihi: 10.08.2016)

UN Office of the United Nations High Commissioner for Human Rights OHCHR (2014b), "Report on the Human Rights Situation in Ukraine", 15 May 2014: 21 http://www.ohchr.org/Documents/Countries/UA/HRMMURep ort15May2014.pdf (erişim tarihi: 10.08.2016)

UN Office of the United Nations High Commissioner for Human Rights OHCHR (2014c), "Report on the Human Rights Situation in Ukraine", 15 July 2014: 14. http://www.ohchr.org/Documents/Countries/UA/Ukraine_Rep ort_15July2014.pdf (erişim tarihi: 10.08.2016)

UN Office of the United Nations High Commissioner for Human Rights OHCHR (2014d), "Report on the Human Rights Situation in Ukraine", 17 August 2014: 4. http://www.ohchr.org/Documents/Countries/UA/UkraineRepor t28August2014.pdf (erişim tarihi: 10.08.2016)

UN Office of the United Nations High Commissioner for Human Rights OHCHR (2015), "Report on the Human Rights Situation in Ukraine", 16 February to 15 May 2015. http://www.ohchr.org/Documents/Countries/UA/10thOHCHR reportUkraine.pdf (erişim tarihi: 10.08.2016)

UN Office of the United Nations High Commissioner for Human Rights OHCHR (2014e), "Report on the Human Rights Situation in Ukraine", $15 \quad$ November 2014. http://www.ohchr.org/Documents/Countries/UA/OHCHR_sixt h_report_on_Ukraine.pdf (erişim tarihi: 10.08.2016)

UN Office of the United Nations High Commissioner for Human Rights OHCHR (2016), "Most Recent Special Procedures' Reports". http://www.ohchr.org/EN/Countries/ENACARegion/Pages/U AIndex.aspx (erişim tarihi: 08.09.2016)

Committee on the Rights of Persons with Disabilities (CRPD) (2015), "Concluding Observations on the Initial Report of Ukraine", 2 Ekim 2015, https://documents-ddsny.un.org/doc/UNDOC/GEN/G15/226/49/PDF/G1522649.p df?OpenElement (erişim tarihi: 08.09.2016) 
Committee against Torture (2014), "Concluding Observations on the Sixth Periodic Report of Ukraine", 12 Aralı 2014, http://docstore.ohcr.org (erişim tarihi: 08.09.2016)

United Nations High Commissioner for Refugees UNHCR, "Who We Are, What We Do in Ukraine", http://unhcr.org.ua/attachments/article/317/UNHCR.\%20Who \%20we\%20are.pdf (erişim tarihi: 08.09.2016)

United Nations High Commissioner for Refugees UNHCR (2015), "UNCHR Assistance to IDPs in Ukraine" http://unhcr.org.ua/en/2011-08-26-06-58-56/news-archive/1319unhcr-assistance-to-idps-in-ukraine (erişim tarihi: 08.09.2016)

United Nations High Commissioner for Refugees UNHCR Ukraine (2015), "Achievements 2015" http://unhcr.org.ua/attachments/article/1231/UNHCR\%20Ukrai ne $\% 20$ Achievements $\% 202015 \% 20$ FINAL.pdf (erişim tarihi: 08.09.2016)

United Nations High Commissioner for Refugees UNHCR (2015) "Eastern Ukraine Quick Impact Projects". http://unhcr.org.ua/attachments/article/317/04202016_QIP\%20 Factsheet.pdf (erişim tarihi: 08.09.2016)

United Nations High Commissioner for Refugees UNHCR (2016a), "UNHCR Ukraine Thematic Factsheet Sexual and Gender-Based Violence", March 2016. http://unhcr.org.ua/attachments/article/317/SGBV\%20April\%2 02016\%20FINAL.pdf (erişim tarihi: 08.09.2016)

United Nations High Commissioner for Refugees UNHCR (2016b), "UNHCR Operational Update", 11 June- 15 July 2016, http://unhcr.org.ua/attachments/article/1299/UNHCR\%20UKR AINE\%20Operational\%20Update\%2015JUL16.pdf (erişim tarihi: 20.11.2017)

United Nations High Commissioner for Refugees UNHCR (2017), "Fact Sheet", 01-30 August 2017, http://unhcr.org.ua/attachments/article/1299/2017\%2008\%20U NHCR $\% 20$ UKRAINE\%20Fact $\% 20$ heet $\% 20$ FINAL $\% 20$ EN.pdf (erişim tarihi: 20.11.2017)

United Nations Development Programme UNDPa, "About UNDP in Ukraine", http://www.ua.undp.org/content/ukraine/en/home/operations/ about_undp.html (erişim tarihi: 08.09.2016) 
United Nations Development Programme UNDPb, “Our Projects", http://www.ua.undp.org/content/ukraine/en/home/operations/ projects/overview.html (erişim tarihi: 15.08.2016)

United Nations "What We Do", http://www.un.org.ua/en/resident-coordinator-system (erişim tarihi: 4.9.2016)

UN Office for the Coordination of Humaniatiran Affairs (OCHA) (2015), "Ukr Displacement_ 21 August 2015", 28.08.2015, http://reliefweb.int/sites/reliefweb.int/files/resources/ukr_displa cement_21_august_2015.pdf (erişim tarihi: 15.09.2016)

UN Office for the Coordination of Humaniatiran Affairs (OCHA) (2016a), "Ukraine- 3W Operational Presence" 28 June 2016, https://www.humanitarianresponse.info/en/system/files/docume nts/files/3w_overview_partners_28_june.pdf (erişim tarihi: 08.09.2016)

UN Office for the Coordination of Humanitarian Affairs (OCHA) (2016b), "Humanitarian Response Plan 2016," 17 February 2016. https://www.humanitarianresponse.info/en/system/files/docume nts/files/2016_hrp_ukraine_english.pdf (erişim tarihi: 08.09.2016)

UN Office for the Coordination of Humanitarian Affairs (OCHA) (2016c), "Ukraine HRP 2015 Achievements", 02 February 2016. https://www.humanitarianresponse.info/en/system/files/docume nts/files/hrp_2015_one_pager_20150203.pdf (erişim tarihi: 08.09.2016)

UN Office for the Coordination of Humanitarian Affairs (OCHA) (2017), "Humanitarian Response Plan Mid Year Review", August 2017, https://www.humanitarianresponse.info/en/operations/ukraine/ document/2017-humanitarian-response-plan-hrp-mid-year-reviewmyr-report, (erişim tarihi: 20.11.2017)

UN Security Council (2015d). Resolution 2202 (2015), 17 February 2015. http://www.securitycouncilreport.org/atf/cf/\%7B65BFCF9B6D27-4E9C-8CD3-CF6E4FF96FF9\%7D/s_res_2202.pdf，(erişim tarihi: 11.04.2016)

UN Security Council (2014a). 7124th Meeting, 1 March 2014, http://www.securitycouncilreport.org/atf/cf/\%7B65BFCF9B6D27-4E9C-8CD3-CF6E4FF96FF9\%7D/s_pv_7124.pdf (erişim tarihi: 07.09.2016)

UN Security Council (2014b). 7125th Meeting, 3 March 2014, http://www.securitycouncilreport.org/atf/cf/\%7B65BFCF9B- 
6D27-4E9C-8CD3-CF6E4FF96FF9\%7D/s_pv_7125.pdf (erişim tarihi: 07.09.2016)

UN Security Council (2014c). 7134th Meeting, 13 March 2014, http:/ / www.securitycouncilreport.org/atf/cf/\%7B65BFCF9B6D27-4E9C-8CD3-CF6E4FF96FF9\%7D/s_pv_7134.pdf (erişim tarihi: 07.09.2016)

UN Security Council (2014ç). 7144th Meeting, 19 March 2014, http:/ /www.securitycouncilreport.org/atf/cf/\%7B65BFCF9B6D27-4E9C-8CD3-CF6E4FF96FF9\%7D/s_pv_7144.pdf (erişim tarihi: 07.09.2016)

UN Security Council (2014d). 7154th Meeting, 13 April 2014, http:/ / www.securitycouncilreport.org/atf/cf/\%7B65BFCF9B-

6D27-4E9C-8CD3 CF6E4FF96FF9\%7D/s_pv_7154.pdf (erişim tarihi: 07.09.2016)

UN Security Council (2014e). 7157th Meeting, 16 April 2016. http:/ / www.securitycouncilreport.org/atf/cf/\%7B65BFCF9B6D27-4E9C-8CD3-CF6E4FF96FF9\%7D/s_pv_7157.pdf (erişim tarihi: 07.09 .2016$)$

UN Security Council (2014f). 7165th Meeting, 29 April 2016. http://www.securitycouncilreport.org/atf/cf/\%7B65BFCF9B6D27-4E9C-8CD3-CF6E4FF96FF9\%7D/s_pv_7165.pdf (erişim tarihi: 07.09.2016)

UN Security Council (2014g). 7167th Meeting, 2 May 2014. http:/ / www.securitycouncilreport.org/atf/cf/\%7B65BFCF9B6D27-4E9C-8CD3-CF6E4FF96FF9\%7D/s_pv_7167.pdf (erişim tarihi: 07.09.2016)

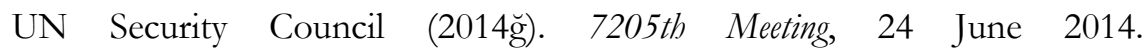
http:/ / www.securitycouncilreport.org/atf/cf/\%7B65BFCF9B6D27-4E9C-8CD3-CF6E4FF96FF9\%7D/s_pv_7205.pdf (erişim tarihi: 07.09.2016)

UN Security Council (2014h). 7287th Meeting, 24 October 2014. http:/ / www.securitycouncilreport.org/atf/cf/\%7B65BFCF9B6D27-4E9C-8CD3-CF6E4FF96FF9\%7D/s_pv_7287.pdf (erişim tarihi: 07.09.2016)

UN Security Council (20141). 7239th Meeting, 8 August 2014. http:/ / www.securitycouncilreport.org/atf/cf/\%7B65BFCF9B6D27-4E9C-8CD3-CF6E4FF96FF9\%7D/s_pv_7239.pdf (erişim tarihi: 07.09.2016) 
UN Security Council (2014i). 7311th Meeting, 12 November 2014. http://www.securitycouncilreport.org/atf/cf/\%7B65BFCF9B6D27-4E9C-8CD3-CF6E4FF96FF9\%7D/s_pv_7311.pdf， (erişim tarihi: 04.04.2016)

UN Security Council (2014j). Draft Resolution S/2014/189, 15 March 2014, http://www.securitycouncilreport.org/atf/cf/\%7B65BFCF9B6D27-4E9C-8CD3-CF6E4FF96FF9\%7D/s_2014_189.pdf (erişim tarihi: 18.03.2016)

UN Security Council (2014k). Resolution 2166 (2014), 7221st Meeting, 21 July 2014.

http://www.securitycouncilreport.org/atf/cf/\%7B65BFCF9B6D27-4E9C-8CD3-CF6E4FF96FF9\%7D/s_res_2166.pdf (erişim tarihi: 28.03.2016)

UN Security Council (2015a). 7400th Meeting, 6 March 2015. http://www.securitycouncilreport.org/atf/cf/\%7B65BFCF9B6D27-4E9C-8CD3-CF6E4FF96FF9\%7D/s_pv_7400.pdf (erişim tarihi: 06.06.2016)

UN Security Council (2015b). 7457th Meeting, 5 June 2015. http://www.securitycouncilreport.org/atf/cf/\%7B65BFCF9B6D27-4E9C-8CD3-CF6E4FF96FF9\%7D/s_pv_7457.pdf (erişim tarihi: 08.09.2016)

UN Security Council (2015c). 7576th Meeting, 11 December 2015. http://www.securitycouncilreport.org/atf/cf/\%7B65BFCF9B6D27-4E9C-8CD3-CF6E4FF96FF9\%7D/s_pv_7576.pdf (erişim tarihi: 08.09.2016)

UN Security Council (2016). 7683rd Meeting, 28 April 2016. http://www.securitycouncilreport.org/atf/cf/\%7B65BFCF9B6D27-4E9C-8CD3-CF6E4FF96FF9\%7D/s_pv_7683.pdf (erişim tarihi: 08.09.2016)

UN Security Council Report (2016), “Chronology of Events”, 6 September 2016 , http:/ /www.securitycouncilreport.org/chronology/ukraine.php, (erişim tarihi: 07.09.2016)

UN Security Council (2017a). 7876th Meeting, 2 February 2017. http://www.securitycouncilreport.org/atf/cf/\%7B65BFCF9B6D27-4E9C-8CD3-CF6E4FF96FF9\%7D/s_pv_7876.pdf (erişim tarihi: 20.11.2017)

UN Security Council (2017b), "Security Council Press Statement on Deterioration of Situation in Donetsk Region, Ukraine" 21 January 
2017, https://www.un.org/press/en/2017/sc12700.doc.htm (erişim tarihi: 20.11.2017) 